\title{
Food as embodied material culture: diversity and change in plant food consumption in Roman Britain
}

\author{
Marijke van der Veen
}

Food as embodied material culture

Food is an area of human life that is intimately linked with both biology and culture. The phrase 'you are what you eat' refers both to the effect food has on one's physical well-being and on the rôle food plays in the expression of one's social and cultural identity. Dietler (2007, 222-23) has fittingly described food as "embodied material culture", a special type of material culture created specifically to be destroyed through ingestion into the human body. He warns, however, that food consumption is neither simply taking on fuel, nor simply the consumption of signs; it also concerns relations of production and exchange and is thus linked to both domestic and political economies. Because food is closely connected with the formation of social and cultural identities, it can form an illuminating topic of study in the context of Roman Britain, for the emergence of multiple identities in that era has been a recent research focus (e.g., Eckardt 2005; James and Millett 2001; Mattingly 2004 and 2006). Here the archaeobotanical evidence for food consumption in Britain is reviewed, concentrating on non-staple foods (fruits, nuts, vegetables, herbs, spices, oil seeds, and wild food plants). The archaeobotanical dataset (514 sites) is analysed with the aim of identifying who consumed which foods, what regional and/or social differentiation existed, and what changes occurred over time.

The impact of the Roman presence on British society and British agriculture has been the subject of considerable debate. The changes observed have often been studied in terms of 'Romanization', a concept emphasizing conformity and describing the hierarchical process of passing down supposedly superior Roman culture and technology to the people of a new province, using the simple opposition of Romans versus Britons. Yet it is increasingly evident that the processes that took place resulted in more complex and varied identities than the term 'Romanization' conveys (James and Millett 2001; Mattingly 2004 and 2006; Webster 2001). Rather than start from a Romano-centric approach and taking a 'top-down' view of British society, this study focuses on the whole of Britain, including those areas never occupied by Rome and those settlements not showing visible signs of Roman influence. By using a contextual approach, I hope to reveal evidence for the emergence of different consumer groups, thereby contributing to the growing body of evidence for diversity and change in Roman Britain.

Food encompasses more than just plant foods. Meat and dairy products, manufactured foods such as fish sauce, olive oil and wine, the containers used to cook, store and transport the food, as well as texts describing their supply, are equally important data for study, but they lie outside the scope of this paper (see, e.g., Bowman 2003; Cool 2006; Grant 2004; King 1999; Lauwerier 2002).

\section{The archaeobotanical evidence}

\section{Archaeobotanical data}

Archaeobotany is concerned with the study of plant remains (primarily macro-fossils such as grains, seeds, nutshells, and fruit stones) recovered from excavations. These remains are used to reconstruct key aspects of human societies, such as past agricultural systems, human impact on vegetation, dietary breadth, trade in foodstuffs, and social access to specific foods. The accuracy of reconstructions is entirely dependent on the quality of the data available for study. The dataset for Roman Britain has recently been assessed (Van der Veen et al. 2007), with lacunae highlighted and research priorities formulated. There are currently 514 sites (representing 639 records; see below for the definition of a 'record') with archaeobotanical data available, but their distribution is biased towards the $E$ and $S$ parts of the country (fig. 1A).

Without some special mechanism for preservation, dead plant tissues on or in the ground normally decay after a number of years. The mode of preservation of archaeobotanical data is 

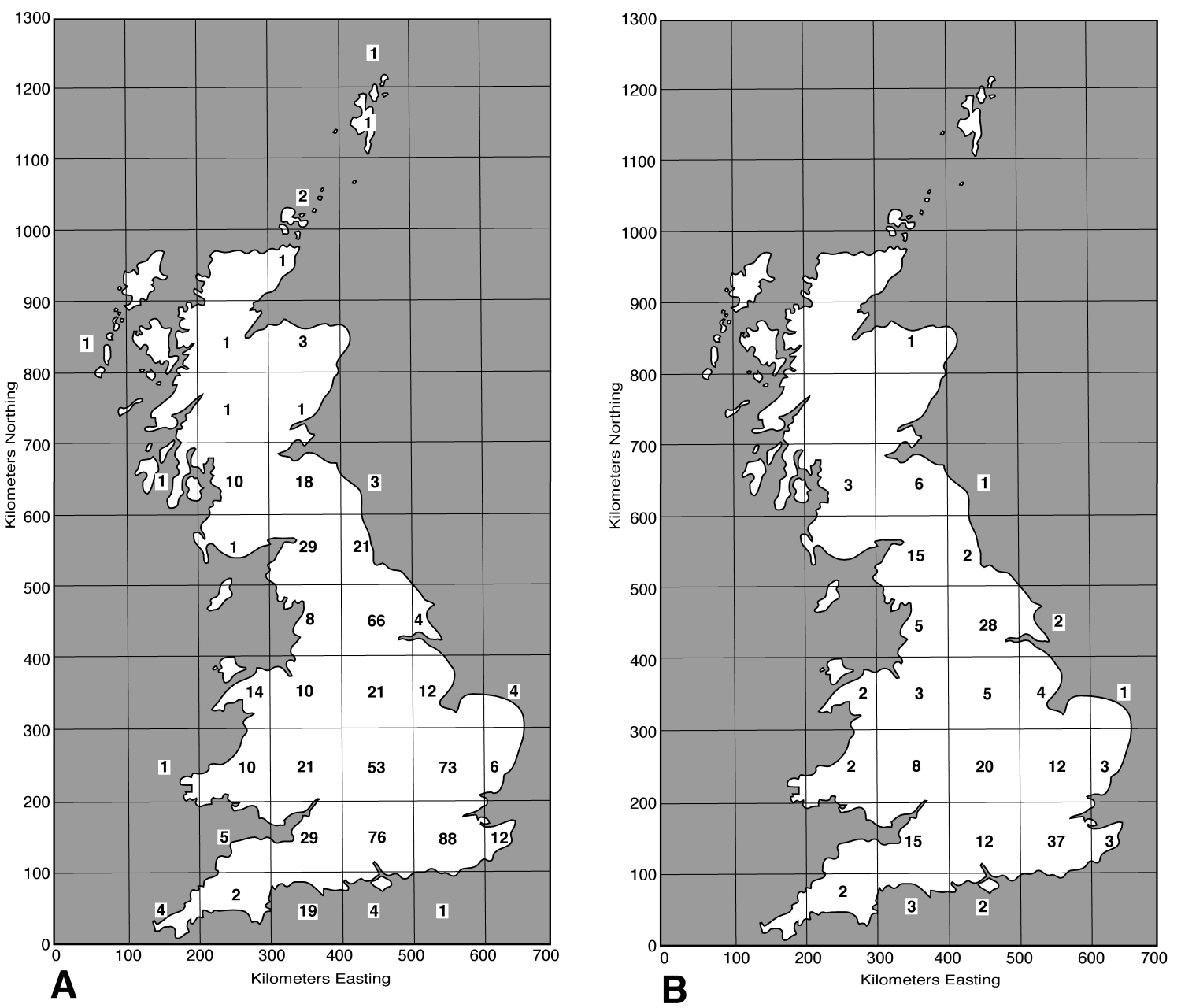

Fig. 1 A-B. Geographical distribution of records with archaeobotanical data:

A: all records and all modes of preservation;

B: all records, waterlogged preservation only. (Each square represents an area of $100 \times 100 \mathrm{~km}$.)

thus a matter of considerable interest. The three most common modes of preservation in Britain (and NW Europe) are carbonization, waterlogging, and mineralization. The type of plant foods recovered is strongly correlated to the type of preservation encountered (fig. 2): foods such as cereals and pulses are almost exclusively found in carbonized form (apart from exceptional situations such as the Swiss lakeshore villages), while fruits, vegetables, herbs, and oil-rich seeds are generally recovered in waterlogged contexts (Van der Veen and Livarda forthcoming). Nuts take an intermediate position, as their shells are frequently recovered in charred as well as waterlogged assemblages. Some fruits, vegetables and herbs are also found in mineralized form, usually in latrines, which are, above all, records of consumption; to date, however, few latrines of Roman date have been sampled in Britain.

This strong correlation between plant type and preservation means that reconstructions of arable strategies, the scale of production and/or the consumption of staples (cereals and pulses) require carbonized plant assemblages, which are found on virtually all settlement sites. If, however, we are interested in the cultivation or consumption of fruits, vegetables, herbs and oil-rich seeds, or variations in the social access to such foods, then waterlogged records are the most informative. Waterlogged preservation is found when the water-table is high, when wells or deep pits are present within the excavated area, or when a deep stratigraphy is recovered. The latter often occurs on long-occupied settlements such as towns and some military sites, where an accumulation of organic-rich deposits creates a burial environment in which the anoxic conditions favour the preservation of plant material, even when full waterlogging is absent. 

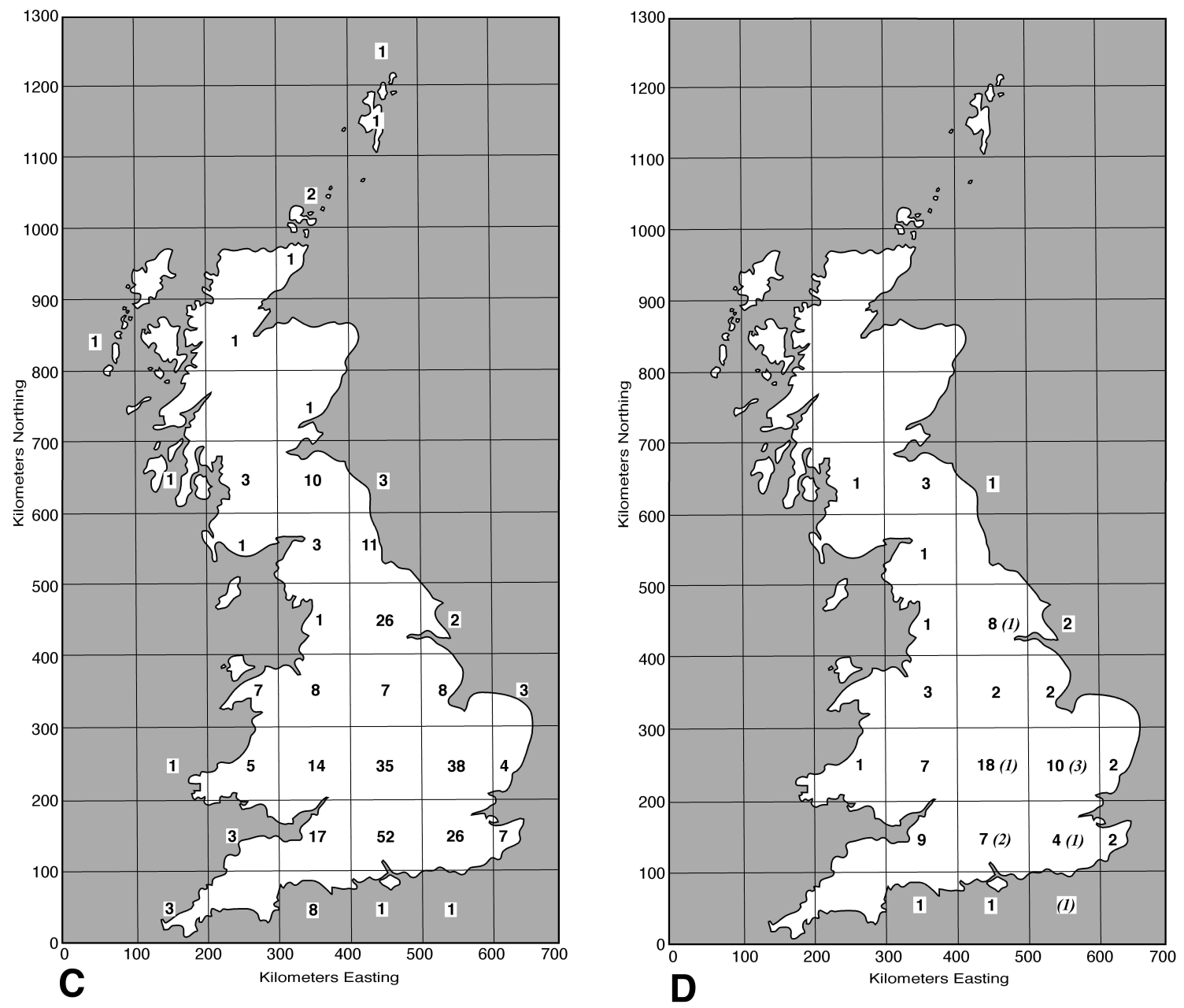

Fig. 1 C-D. Geographical distribution of records with archaeobotanical data:

C: rural records, minor towns and industrial sites, carbonized preservation only;

D: rural records, minor towns and industrial sites, waterlogged preservation with mineralized preservation in brackets (Each square represents an area of $100 \times 100 \mathrm{~km}$.)

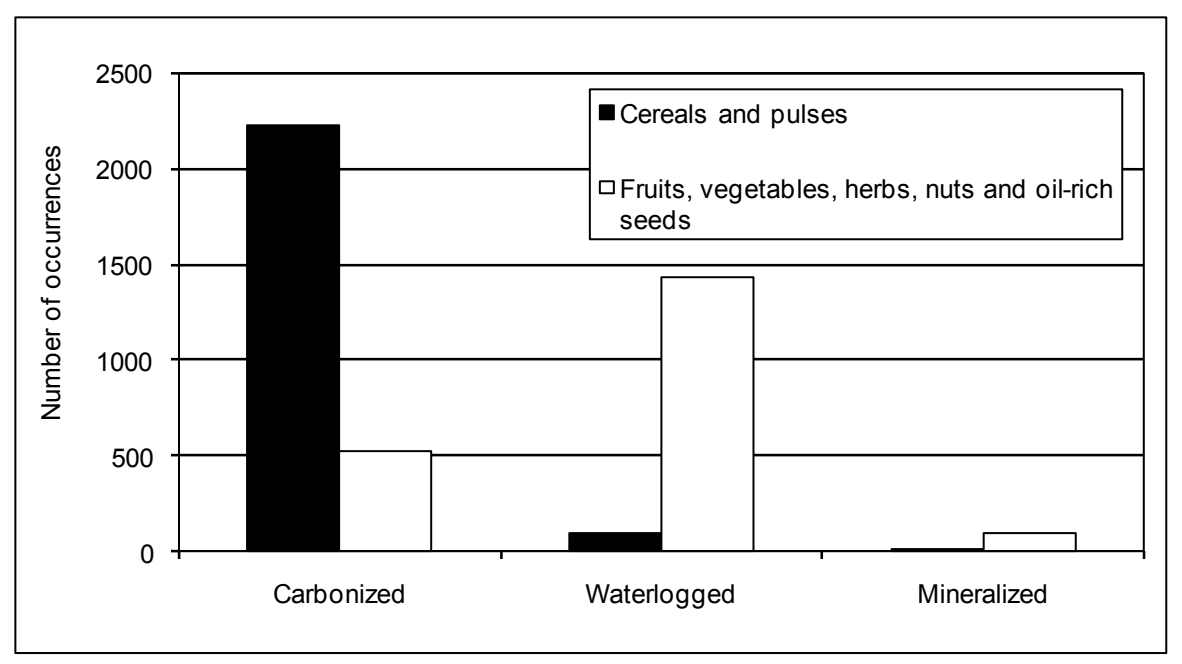

Fig. 2. Predominant mode of preservation for the two main food groups, based on the number of occurrences of each food in the archaeobotanical records from Roman Britain. 


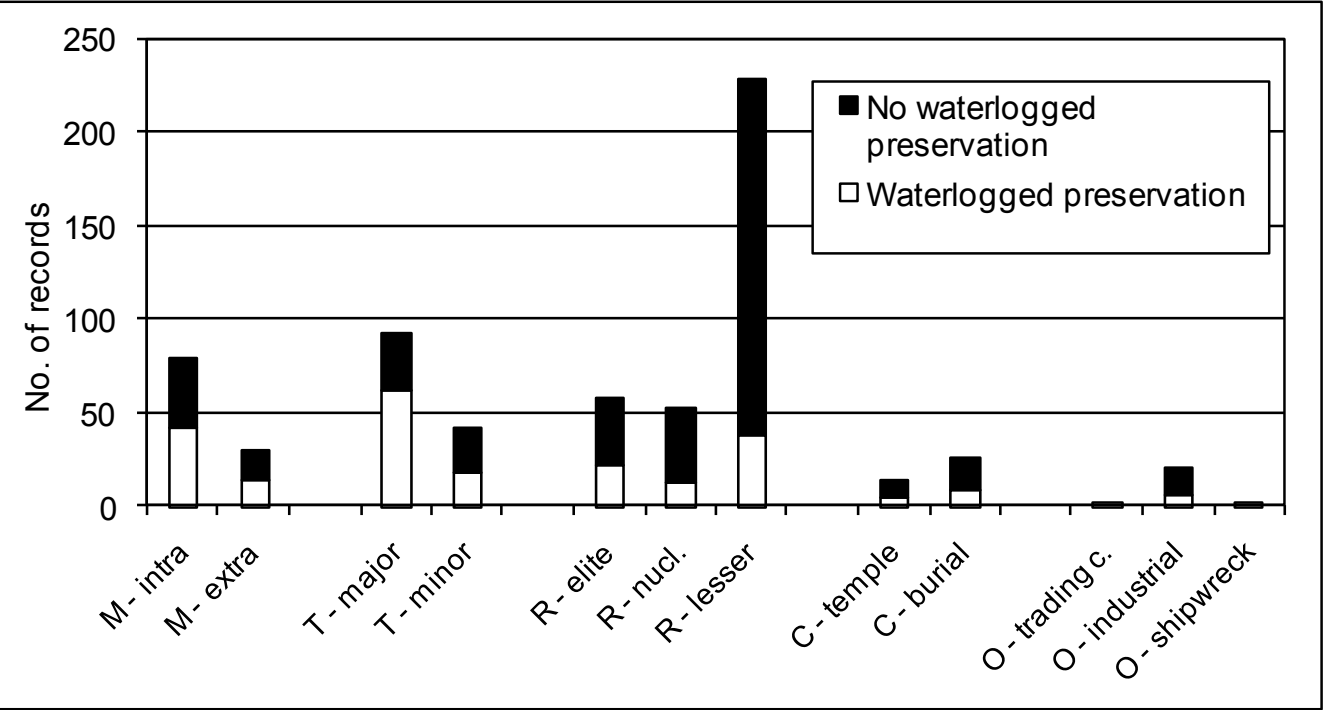

Fig. 3. Number of waterlogged records against the total number of records with archaeobotanical data, by detailed site type: $\mathrm{M}=$ military; $\mathrm{T}=$ town; $\mathrm{R}=$ rural; $\mathrm{C}=$ ceremonial; $\mathrm{O}=$ other.

In Britain and most of NW Europe, carbonization is the most frequently encountered mode of preservation, with waterlogging much less common, and mineralization only sporadic. In regions where no sites with waterlogged preservation have been excavated and sampled, we are unable to make inferences about food consumption of non-staple foods. In Roman Britain the distribution of sites with waterlogged preservation is skewed (figs. 1B and 1D), with resultant major gaps in our knowledge for most of Scotland, NW Britain, Wales, and SW Britain. There is also a bias in site type: while about half the records from urban and military sites have some degree of waterlogged preservation, the figure drops to a fifth for rural sites, and just $17 \%$ for small farmsteads ('rural lesser' sites; fig. 3).

\section{Data recorded}

Data were collected from all archaeobotanical reports relevant to Roman Britain (see Van der Veen et al. 2008 for a more detailed description of methodology and data analysis). Data collection stopped in early 2006. The term Roman Britain here refers to England, Wales and Scotland, including those parts never occupied by Rome. The presence of all food plants (cultivated and wild foods) was recorded, along with information about the exact location (National Grid Reference) and nature of the site, chronology, and mode of preservation of each food plant. Only presence/absence was recorded; no numerical abundance was used because of the sheer complexity of standardizing data from reports using very varied methodologies, though if a species was particularly abundant that was noted.

To study social differences in access to certain foods, the sites were classified into a series of types, which identify broad social and cultural groupings. The allocation of rural sites to type was far from clear-cut: it is based on size of settlement and type of architectural features present, but information on both is influenced by scale of excavation. The difference between 'town minor' and 'rural nucleated' is one of degree. (While the site types are by necessity broad, to take account of the size and quality of the database, they are more detailed than those used in previous studies.)

$$
\begin{aligned}
\text { Rural } & \text { - lesser (farmstead, hamlet) } \\
& \text { - nucleated (village) } \\
& \text { - élite (villa) }
\end{aligned}
$$

Urban - town major (colonia, municipium, civitascapital) - town minor ('small' town)

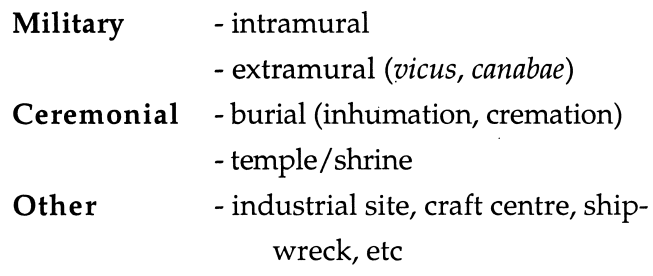




\title{
Diversity and change in plant food consumption in Roman Britain
} 87

TABLE 1

\author{
LIST OF FOOD PLANTS CONSIDERED IN THIS PAPER
}

(n) wild form of this food is native to Britain; (?n) possibly native; (?intrd.) probably introduced (after Stace 1997)

\section{Cereals}

millet, Panicum miliaceum

einkorn, Triticum monococcum

Pulses

lentil, Lens culinaris

bitter vetch, Vicia ervilia

Fruits

fig, Ficus carica

grape, Vitis vinifera

mulberry, Morus nigra

olive, Olea europea

peach, Persica vulgaris

date, Phoenix dactylifera

pomegranate, Punica granatum

apple, Malus sp. (n)

pear, Pyrus sp.

sweet cherry, Prunus avium (n)

sour cherry, Prunus cerasus

cherry plum, Prunus cerasifera

plum, Prunus domestica ssp. domestica

damson, Prunus domestica ssp. insititia

Nuts

walnut, Juglans regia

pine nut, Pinus pinea

almond, Amygdalus communis

chestnut, Castanea sativa

Vegetables

leaf beet, Beta vulgaris (n)

rape, Brassica napus

cabbage, Brassica oleracea (?n)

turnip, Brassica rapa (?intrd.)

leek, Allium porrum

cucumber, Cucumis sativus

carrot, Daucus carota (n)

parsnip, Pastinaca sativa (n)

lettuce, Lactuca sativa

asparagus, Asparagus officinalis (n)

\section{Condiments}

black pepper, Piper nigrum

coriander, Coriandrum sativum

dill, Anethum graveolens

celery, Apium graveolens (n)

fennel, Foeniculum vulgare (?intrd.)

parsley, Petroselinum crispum

anise, Pimpinella anisum

summer savory, Satureja hortensis

marjoram, Origanum vulgare (n)

mint, Mentha sp. (n)

horehound, Marrubium vulgare (n)

black cumin, Nigella sativa

rue, Ruta graveolens

white mustard, Sinapis alba

lovage, Levisticum officinale

Oil-rich seeds

sesame, Sesamum indicum

gold of pleasure, Camelina sativa

hemp, Cannabis sativa

poppy seed, Papaver somniferum (?intrd.)

black mustard, Brassica nigra

Other

hop, Humulus lupulus (n)

Wild foods

hazelnut, Corylus avellana (n)

blackberry, Rubus fruticosus (n)

raspberry, Rubus idaeus (n)

sloe, Prunus spinosa (n)

wild strawberry, Fragaria vesca (n)

rosehip, Rosa spp. (n)

elderberry, Sambucus nigra (n)

bilberry, Vaccinium $s p$. (n)

crowberry, Empetrum nigra (n)

rowan, Sorbus aucuparia (n)

dewberry, Rubus caesius (n)

hawthorn, Crataegus sp. (n)

The term 'record' is used to refer to the smallest unit of analysis employed. It concerns archaeobotanical data from a distinct phase of occupation and/or a distinct site type. For example, data from phases I and II at site A represent two records; similarly data from a group of burials, a shrine and an occupation area at Early Roman site B represent three records. In total, the dataset consists of 639 records. The start- and end-date of each record was recorded, to the level of precision available from the publication or report. Subsequently, each record was allocated a broad chronological phase (Early, Middle, Late Roman). These phases are defined as follows:

Early Roman records dated to the 1st c. A.D., including those continuing into the 2nd c. Also included are Late Iron Age sites where the occupation continued into the 1st or early 2nd c. A.D.

Mid-Roman records dated to the 2 nd and 3rd c. A.D.

Late Roman records dated to the 4 th c. A.D., including those that started in the 3rd but continued into the 4 th c.

Roman $\mathbf{m} / \mathbf{1}$ records dated no more specifically than 2 nd-4th c. A.D.

Roman no dating evidence beyond 'Roman', plus records dated very broadly to the 1st-3rd c. A.D.

The data analysis is based on all waterlogged records unless stated otherwise: most of the foods analysed here are found either exclusively or predominantly in waterlogged modes of 
TABLE 2

TOTAL NUMBER OF RECORDS OF EACH NEW FOOD, BY TYPE OF SITE

(waterlogged, carbonized and mineralized occurrences combined; for abbreviations, see fig. 3 caption)

\begin{tabular}{|c|c|c|c|c|c|c|c|c|c|c|c|c|c|}
\hline & $\begin{array}{l}\mathrm{M} \\
\text { intra }\end{array}$ & $\begin{array}{c}\mathrm{M} \\
\text { extra }\end{array}$ & $\begin{array}{c}\mathrm{T} \\
\text { major }\end{array}$ & $\begin{array}{c}\mathrm{T} \\
\text { minor }\end{array}$ & $\begin{array}{l}\mathrm{R} \\
\text { élite }\end{array}$ & $\begin{array}{l}\mathrm{R} \\
\text { nucl }\end{array}$ & $\begin{array}{c}\mathrm{R} \\
\text { lesser }\end{array}$ & $\begin{array}{l}\mathrm{O} \\
\text { indus }\end{array}$ & $\begin{array}{c}\mathrm{O} \\
\text { trading }\end{array}$ & $\begin{array}{c}\text { O } \\
\text { shipw }\end{array}$ & $\begin{array}{c}\mathrm{C} \\
\text { burial }\end{array}$ & $\begin{array}{l}\text { C } \\
\text { temple }\end{array}$ & e Total \\
\hline Fig & 15 & 6 & 50 & 8 & 3 & 2 & 1 & . & 1 & . & 5 & & 91 \\
\hline Coriander & 17 & 6 & 29 & 5 & 6 & 4 & 6 & 1 & . & . & . & & 74 \\
\hline Poppy seed & 13 & 3 & 27 & 4 & 10 & 4 & 8 & 3 & . & . & 1 & & 73 \\
\hline Apple/pear & 8 & 5 & 29 & 5 & 6 & 6 & 7 & & . & . & 1 & 1 & 68 \\
\hline Mint & 9 & 4 & 16 & 2 & 4 & 4 & 15 & 5 & . & . & 1 & 2 & 62 \\
\hline Grape & 10 & 4 & 33 & 3 & 5 & . & 2 & . & . & 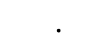 & 4 & 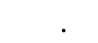 & 61 \\
\hline Celery & 13 & 6 & 16 & 3 & 3 & 2 & 3 & 1 & . & . & 1 & 1 & 49 \\
\hline Carrot & 3 & 1 & 15 & 2 & 5 & 3 & 13 & . & . & . & . & . & 42 \\
\hline Dill & 12 & 4 & 20 & 1 & 1 & 1 & 1 & . & . & . & . & . & 40 \\
\hline Cherries & 5 & 1 & 20 & 4 & 2 & 3 & 5 & . & . & . & . & . & 40 \\
\hline Damson & 7 & 2 & 16 & 2 & 1 & 3 & 5 & 1 & . & . & 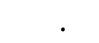 & . & 37 \\
\hline Plum & 2 & 2 & 16 & 5 & 4 & . & 5 & . & . & . & & . & 34 \\
\hline Pine nut & 3 & 1 & 12 & 1 & 6 & 2 & & 1 & . & . & 1 & 5 & 32 \\
\hline Lentil & 3 & 2 & 18 & . & . & 1 & 2 & . & . & . & 3 & . & 29 \\
\hline Walnut & 3 & 3 & 15 & 1 & 4 & 1 & 1 & . & . & . & . & . & 28 \\
\hline Turnip & 6 & 4 & 3 & . & 3 & 1 & 5 & 2 & . & . & . & . & 24 \\
\hline Mulberry & . & . & 18 & . & . & . & . & . & . & . & 1 & 1 & 20 \\
\hline Black mustard & 4 & 2 & 8 & 1 & 1 & 1 & 1 & . & . & . & 1 & . & 19 \\
\hline Summer savory & 3 & . & 10 & . & 2 & 2 & 2 & . & . & . & . & . & 19 \\
\hline Hemp & 4 & . & 12 & . & 1 & . & . & . & . & . & . & . & 17 \\
\hline Olive & 4 & 1 & 9 & 1 & 1 & . & . & . & . & 1 & . & . & 17 \\
\hline Parsnip & 4 & 2 & 3 & & 2 & 1 & 3 & . & . & . & . & . & 15 \\
\hline Fennel & 1 & . & 9 & 1 & 1 & 1 & . & . & . & . & . & . & 13 \\
\hline Leaf beet & 1 & . & 7 & 1 & 2 & . & . & . & . & . & . & . & 11 \\
\hline Gold of pleasure & 1 & . & 7 & . & . & . & . & . & . & . & . & . & 8 \\
\hline Cabbage & 3 & . & 2 & 1 & . & . & . & . & . & . & . & . & 6 \\
\hline Millet & 3 & . & 3 & . & . & . & . & . & . & . & . & & 6 \\
\hline White mustard & 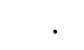 & . & 5 & . & . & . & 1 & . & . & . & . & 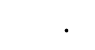 & 6 \\
\hline Cucumber & & . & 5 & . & . & . & . & . & . & . & . & . & 5 \\
\hline Hop & 2 & . & 3 & . & . & . & . & . & . & . & . & . & 5 \\
\hline Marjoram & . & 1 & 3 & . & 1 & . & . & . & . & . & . & . & 5 \\
\hline Almond & & 1 & 2 & . & . & . & . & . & . & . & 1 & . & 4 \\
\hline Date & 2 & 1 & . & . & . & . & . & . & 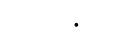 & . & 1 & . & 4 \\
\hline Leek & 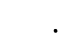 & . & 1 & . & . & 1 & . & . & . & . & . & . & 2 \\
\hline Asparagus & 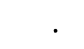 & . & . & 2 & . & . & . & . & . & . & . & . & 2 \\
\hline Rape & 1 & . & . & . & 1 & . & . & . & . & . & . & . & 2 \\
\hline Black cumin & 1 & . & 1 & . & . & . & . & . & . & . & . & . & 2 \\
\hline Parsley & . & 1 & 1 & . & . & . & . & . & . & . & . & . & 2 \\
\hline Bitter vetch & . & . & 2 & . & . & . & . & . & . & . & . & . & 2 \\
\hline Black pepper & . & . & 1 & . & . & . & . & . & . & . & . & . & 1 \\
\hline Chesnut & . & . & . & . & 1 & . & . & . & . & . & . & . & 1 \\
\hline Lettuce & . & . & . & . & 1 & . & . & . & . & . & . & . & 1 \\
\hline Lovage & . & . & 1 & . & . & . & . & . & . & . & . & . & 1 \\
\hline Horehound & . & . & 1 & . & . & . & . & . & . & . & . & . & 1 \\
\hline Peach & . & . & 1 & . & . & . & . & . & . & . & . & . & 1 \\
\hline Aniseed & . & . & 1 & . & . & . & . & . & . & . & . & & 1 \\
\hline Pomegranate & . & . & 1 & . & . & . & . & & . & . & . & & 1 \\
\hline Rue & . & . & 1 & . & . & . & . & & . & . & . & & 1 \\
\hline Sesame & & 1 & . & & & & . & & . & . & . & & 1 \\
\hline TOTAL & 163 & 64 & 453 & 53 & 77 & 43 & 86 & 14 & 1 & 1 & 21 & 10 & 986 \\
\hline
\end{tabular}




\section{Diversity and change in plant food consumption in Roman Britain}

TABLE 3

TOTAL NUMBER OF RECORDS OF EACH WILD FOOD, BY TYPE OF SITE

(waterlogged, carbonized and mineralized occurrences combined; for abbreviations, see fig. 3 caption)

\begin{tabular}{|c|c|c|c|c|c|c|c|c|c|c|c|c|c|}
\hline & $\begin{array}{l}\mathrm{M} \\
\text { intra }\end{array}$ & $\begin{array}{c}\mathrm{M} \\
\text { extra }\end{array}$ & $\begin{array}{c}\mathrm{T} \\
\text { major }\end{array}$ & $\begin{array}{c}\mathrm{T} \\
\text { minor }\end{array}$ & $\begin{array}{l}\mathrm{R} \\
\text { élite }\end{array}$ & $\begin{array}{l}\mathrm{R} \\
\text { nucl }\end{array}$ & $\begin{array}{c}\mathrm{R} \\
\text { lesser }\end{array}$ & $\begin{array}{c}\mathrm{O} \\
\text { indus }\end{array}$ & $\begin{array}{c}\mathrm{O} \\
\text { trading }\end{array}$ & $\begin{array}{c}\mathrm{O} \\
\text { shipw }\end{array}$ & $\begin{array}{c}\mathrm{C} \\
\text { burial }\end{array}$ & $\begin{array}{c}\text { C } \\
\text { temple }\end{array}$ & Total \\
\hline Hazelnut & 40 & 15 & 46 & 17 & 17 & 18 & 71 & 7 & 1 & 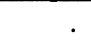 & 9 & 4 & 245 \\
\hline Elderberry & 24 & 6 & 54 & 10 & 16 & 14 & 32 & 6 & . & . & 6 & 6 & 174 \\
\hline Black-/raspberry & 28 & 8 & 48 & 8 & 13 & 10 & 36 & 7 & . & . & 4 & 3 & 165 \\
\hline Sloe & 12 & 7 & 28 & 5 & 9 & 7 & 23 & 2 & . & . & 3 & 1 & 97 \\
\hline Hawthorn & 3 & 2 & 6 & 4 & 9 & 7 & 16 & ${ }^{\circ}$ & . & . & 1 & 2 & 50 \\
\hline Wild strawberry & 14 & 2 & 17 & 3 & 1 & . & 5 & . & . & . & 2 & . & 44 \\
\hline Rosehip & 3 & 4 & 6 & 3 & 6 & 5 & 13 & . & . & . & ${ }^{\circ}$ & 1 & 41 \\
\hline Bilberry & 11 & 1 & 2 & 1 & & 1 & 2 & . & . & . & 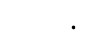 & . & 18 \\
\hline Rowan & 1 & 2 & 2 & . & 1 & . & 3 & . & . & . & 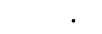 & . & 9 \\
\hline Crowberry & 4 & 1 & . & . & & . & 1 & . & . & ${ }^{\circ}$ & . & . & 6 \\
\hline Dewberry & 1 & . & 1 & . & 1 & 1 & & 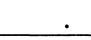 & . & & & & 4 \\
\hline TOTAL & 141 & 48 & 210 & 51 & 73 & 63 & 202 & 22 & 1 & 0 & 25 & 17 & 853 \\
\hline
\end{tabular}

preservation. As waterlogged preservation is mostly a factor of local topography, there is no reason to assume that food consumption on sites with waterlogged preservation was different from those where waterlogging did not occur. Accordingly, the food consumption patterns detected on sites with waterlogged preservation are taken as representative of the plant food consumption at all sites. It is worth stressing, however, that the actual percentage change of each food reached on the basis of these calculations should be taken as guidance only. Thus, where we see an increase of grapes from 5 to $25 \%$, this denotes a significant increase in the availability and consumption of grapes, rather than exactly a fivefold increase. The figures should be read as proportional to one another, not as actual percentages.

The food plants considered are all those encountered in the archaeobotanical dataset from Roman Britain (Table 1), with the exception of the main staples - i.e., the cereals (wheat, barley, oat, rye), pulses (peas, beans), and oil seeds (linseed), to be considered elsewhere. However, as einkorn (Triticum monococcum), millet (Panicum miliaceum) and lentil (Lens culinaris) represent imports, they have been included here.

In total, some 60 food plants have been recovered from Roman-period sites in Britain (over and above the cereals and pulses), but many have been found only rarely (Tables 2-3). Of the native wild food plants, hazelnut, elderberry and black- or raspberry are the most numerous (note that the seeds of elderberry and blackberry may derive from plants growing on wasteland near settlements - they need not represent food remains; the same may be true of hawthorn). Of the cultivated foods, fig, coriander, poppy seed, apple, mint, and grape are the most frequent. Both types of food plant are found across the entire country, though most records are found south of the Antonine Wall (but there are virtually no waterlogged records north of that wall; fig. 1B).

While the majority of the foods discussed in this paper are first encountered in the Roman period, some food imports started to arrive during the Late Iron Age. For example, remains of amphorae that would have contained wine, olive oil, and/or fish products have been found in SE England, primarily in the graves of wealthy individuals (Hill 1995a), and two bones of Spanish mackerel (Scomber colias), thought to represent trade with the Biscay coast of France, were recovered at the Late Iron Age élite settlement of Skeleton Green (Herts.) (Wheeler 1981). Currently the only archaeobotanical record of imported food plants dated to the Late Iron Age known to me is the fig seed from Hengistbury Head (Cunliffe 2000,191-92). This may simply be something one of the traders arriving at the port had eaten on the journey, but recent finds of coriander, celery, dill, fennel, fig, and damson at selected Late Iron Age sites in Germany, France and Switzerland (Kreuz 2004) suggest that the importation of these 'raw' foodstuffs started as early as the 'processed' foods (wine and oil), if on a limited scale and in selected regions. There is no evidence that preservation biases play a rôle here (see p. 100 below). Thus, current evidence suggests that some new foods started to arrive in Britain prior to the Roman 


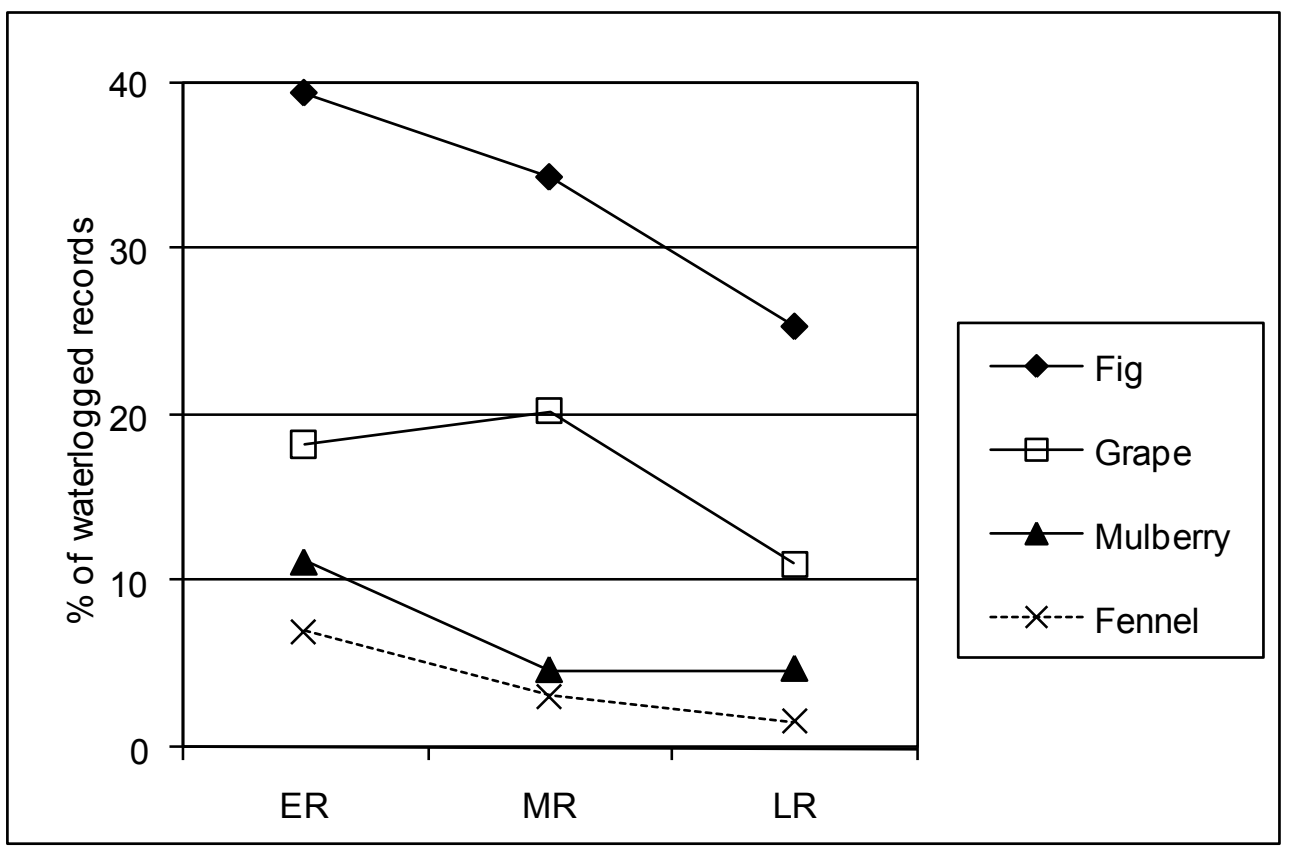

Fig. 4. Chronological distribution: relative proportion of each food by phase of occupation (waterlogged records only). Group A: foods that decline over time. ER = Early Roman; MR = mid-Roman; LR = Late Roman. conquest, but after it this process increased in both scale and range.

\section{Dispersal of the foods (chronology, social and regional access)}

Chronological pattern

To analyse the dispersal of the new foods, the number of waterlogged records with each food was expressed as a proportion of all waterlogged records for each phase. This resulted in three patterns (figs. 4-6): some foods decreased in frequency over time, some initially increased but then declined, while others increased in frequency over the duration of the Roman period.

Group A: Foods that decline over time

The foods that decline in frequency almost from the moment they are introduced are fig, mulberry, fennel (waterlogged records; see fig. 4), and lentil (carbonized records; not shown). Grape is added to this group, even though initially it increases slightly, as its overall pattern is downward. Of these foods, fig is remarkably common; while declining over time, it is still present on 25\% of records (a drop from 39\%) in the Late Roman period, and is still found in $69 \%$ of Late Roman major towns. Grapes drop from 18 to $11 \%$, but are still present in $25 \%$ of major towns in the Late Roman period. Mulberry, fennel and lentil are never very common, but also decline over time.

Group B: Foods that initially increase in frequency, but then decline

The foods that increase from the Early to the Middle Roman period but then drop back to Early Roman levels by the Late Roman period are: coriander, celery, dill, summer savory, poppy seed, mint, parsnip, apple/pear, turnip, pine nut, olive (fig. 5). The Late Roman value of most of these foods lies between +2 and $-2 \%$ of the Early Roman value. Exceptions are: dill (ends $8 \%$ lower), celery (ends $4 \%$ higher), and olive (ends $4 \%$ lower). In this group, coriander is the most abundant, starting at $28 \%$ and rising to just over $40 \%$ of waterlogged records by the Middle Roman period. Poppy seed, mint, celery and dill are also quite common, reaching more than $25 \%$ of waterlogged records in the Middle Roman period.

Group C: Foods that increase over time and appear to become established

Foods that increase in occurrence during the Roman period are: carrot, cherry, plum, black mustard, damson, walnut, hemp, beet, cabbage (fig. 6). Of these, carrot, cherry and plum reach more 


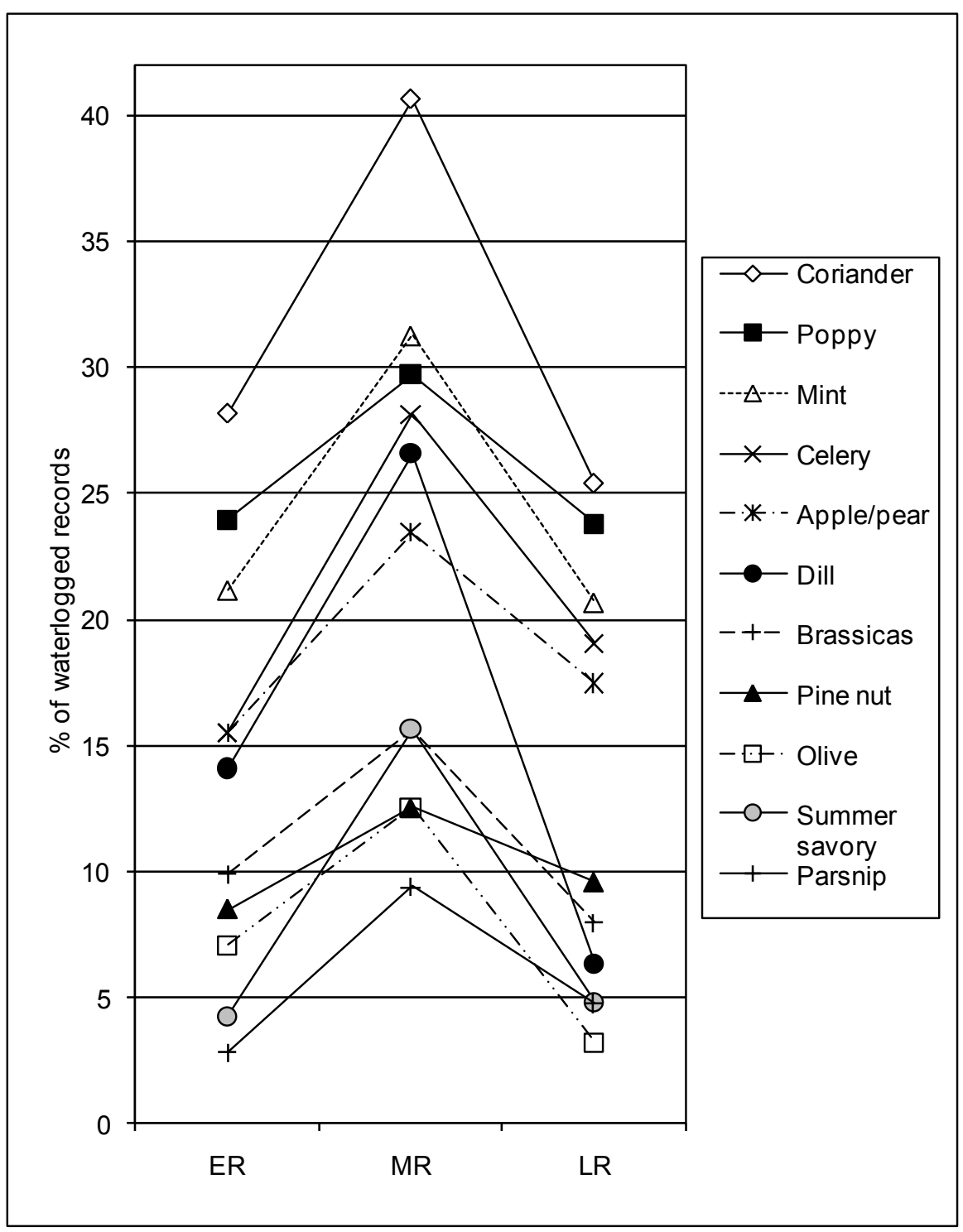

Fig. 5. Chronological distribution: relative proportion of each food by phase of occupation (waterlogged records only). Group B: foods that initially increase but then decline. ER = Early Roman; MR = midRoman; LR = Late Roman.

than $15 \%$ of waterlogged records by the Late Roman period. Damson, plum and walnut take a slightly anomalous position within this group: they show the up/down pattern of the previous group, but as they end with values considerably higher than their starting point (walnut rises from 7 to $13 \%$, damson from 7 to $14 \%$ ) they have been placed within this group.

Since there are many factors influencing the numerical frequency of a food in any one phase (degree of waterlogged preservation on any one site, number and type of sites excavated in each phase, size of excavation, number of samples analysed, quality of the identifications, and so on), we should not expect completely coherent groups; some foods are likely to display variant patterns. Yet if we take this into account, the groups are remarkably consistent. Group A comprises mostly foods that were never widely cultivated in Britain - they were, and mostly still are, imports. Group B is characterized by a large number of herbs, but includes some fruits and vegetables; it is the most varied group, including some species that remain imports (olive, 


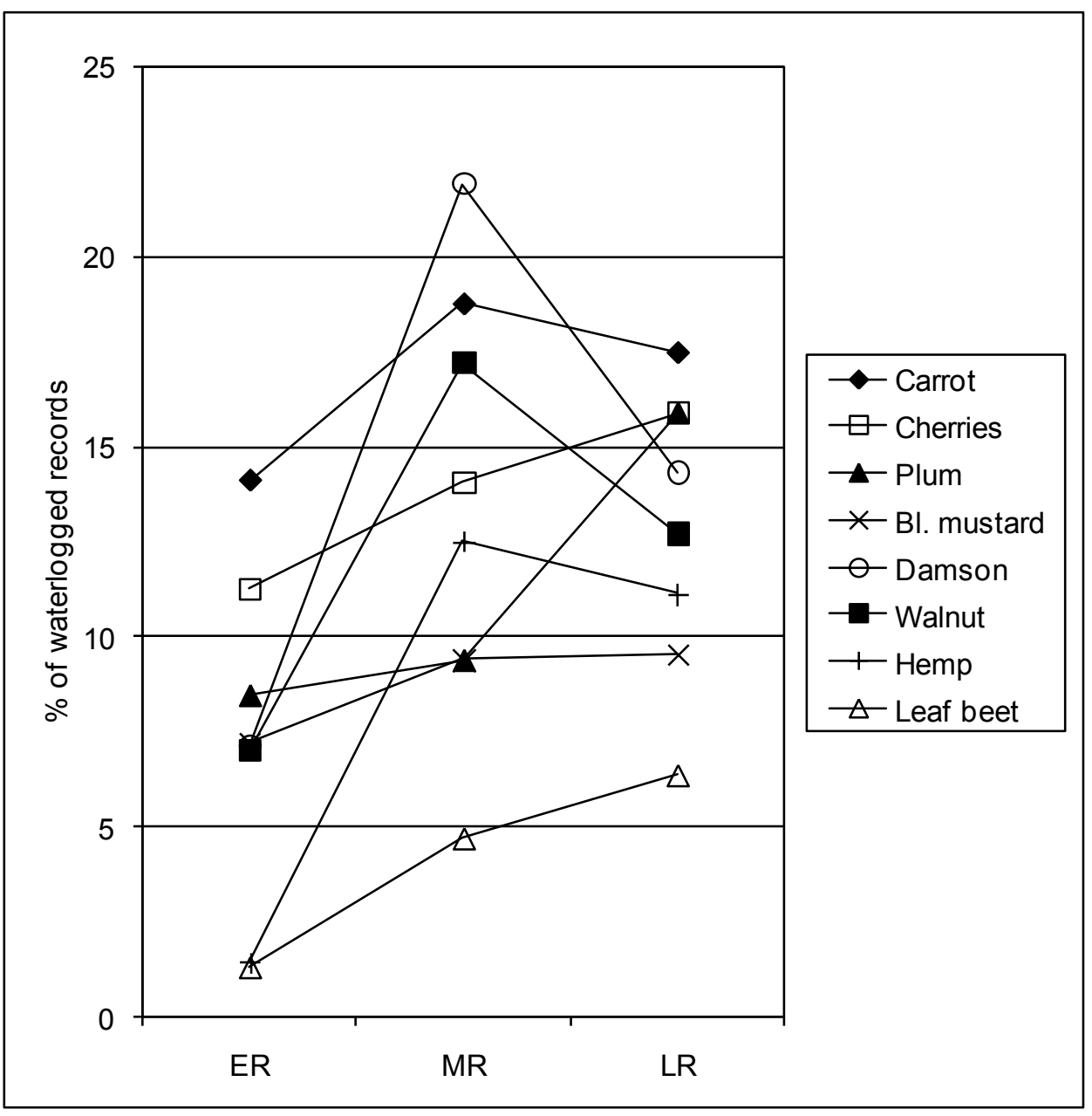

Fig. 6. Chronological distribution: relative proportion of each food by phase of occupation (waterlogged records only). Group C: foods increasing over time. ER = Early Roman; MR = mid-Roman; LR = Late Roman.

TABLE 4

OCCURRENCE OF WILD FOODS BY PERIOD

(waterlogged records only)

\begin{tabular}{lccccc} 
& $\begin{array}{c}\text { Total number } \\
\text { of records }\end{array}$ & $\begin{array}{c}\text { Early Roman } \\
(\mathrm{N}=71)\end{array}$ & $\begin{array}{c}\text { Mid Roman } \\
(\mathrm{N}=64)\end{array}$ & $\begin{array}{c}\text { Late Roman } \\
(\mathrm{N}=63)\end{array}$ & $\begin{array}{c}\text { Change ER to } \\
\text { LR }\end{array}$ \\
\hline & $\mathrm{N}$ & \% of records & $\%$ of records & $\%$ of records & \\
Elderberry & 121 & 54.9 & 64.1 & 65.1 & 10.2 \\
Black-/raspberry & 119 & 59.2 & 62.5 & 58.7 & -0.5 \\
Hazelnut & 86 & 33.8 & 54.7 & 42.9 & 9.1 \\
Sloe & 51 & 19.7 & 31.3 & 27.0 & 7.3 \\
Hawthorn & 34 & 11.3 & 10.9 & 30.2 & 18.9 \\
Wild strawberry & 32 & 19.7 & 14.1 & 14.3 & -5.4 \\
Rosehip & 27 & 5.6 & 15.6 & 20.6 & 15.0 \\
Bilberry & 15 & 7.0 & 9.4 & 6.3 & -0.7 \\
Rowan & 4 & 2.8 & 1.6 & 1.6 & -1.2 \\
Crowberry & 3 & 2.8 & 1.6 & 0.0 & -2.8 \\
Dewberry & 2 & 0.0 & 3.1 & 0.0 & 0.0
\end{tabular}



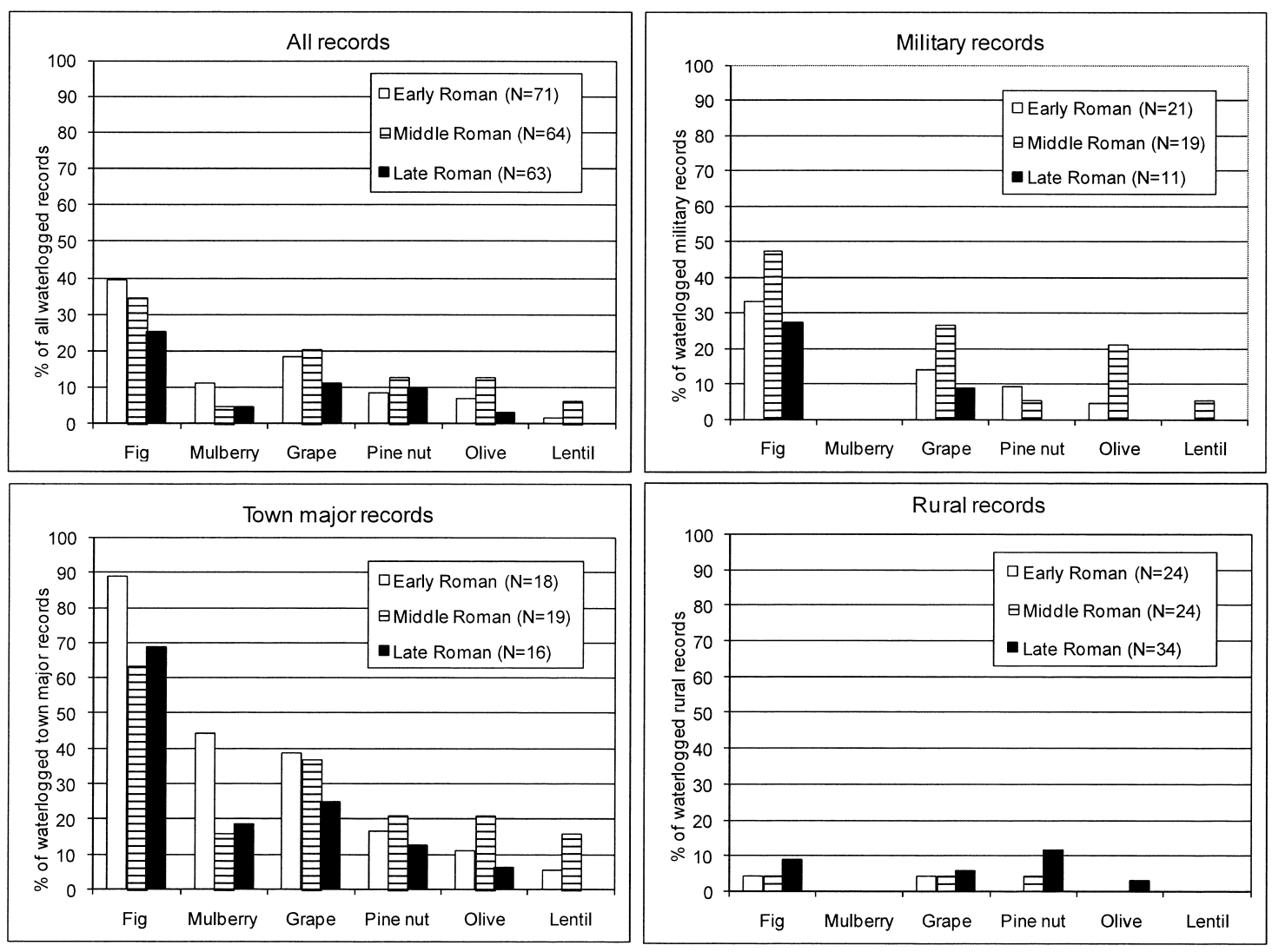

Fig. 7. Ubiquity of the 'exotic' foods by phase (waterlogged records only), expressed as the proportion of records with each food, by site category. Rural group includes minor towns and industrial sites.

pine nut) and some that fit better with Group C (apple/pear, turnip). Group C comprises fruits and vegetables that are widely cultivated in Britain today (e.g., cherry, plum, cabbage).

In terms of wild foods, hazelnut, sloe, hawthorn, rosehip and elderberry increase in frequency, while black-/raspberry stays stable and wild strawberry sees a small decline (Table 4).

Variation by site type

A key component of the project was to determine who had or gained access to these new foods. Were the new foods exclusively available to the élite, did this change over time, which foods were obtainable in the countryside, what regional variability existed, and who was consuming the wild foods? It goes without saying that the site classification used can lead only to a crude attempt at determining social access - each type of site will have comprised inhabitants of different social status - but it is the best data available. Three ways of answering these questions have been deployed. Firstly, the occurrence of each food is given by site type (Tables 2-3, fig. 7); secondly, each site type is characterized by the average, median and maximum number of new foods (Table 5); finally, a multivariate analysis has been conducted (fig. 8). The latter is necessary because any classification of the sites (or foods) into groups inevitably obscures wrong classifications, outliers, and variability within each group. Multivariate pattern seeking analyses, such as Correspondence Analysis, help reveal the degree of variability within each site classification and show which foods tend to co-occur.

Here Canoco version 4.5 (Ter Braak and Smilauer 2002) was used. It allows each site and each food to be entered into the analysis irrespective of their classification. It identifies differences between records on the basis of their food composition (not their classification as 'town major', 'town minor', etc.) and the results are plotted on two-dimensional plots (generally only the first two axes are plotted). The first, horizontal axis identifies the main variation within the records; it plots records that are dissimilar to one another at opposite 
TABLE 5

TOTAL, AVERAGE, MEDIAN AND MAXIMUM NUMBER OF NEW FOODS, BY TYPE OF SITE

(waterlogged records only)

Total no.Total with \% with Total no. Max no. Average Median no. Stdev waterlog. new foods new foods new foods per record no. new new foods records found

per record no. new new foods foods

Military intramural
Military extramural
Town major
Town minor
Rural élite
Rural nucleated
Rural lesser
Industrial sites
Port of trade
Shipwreck
Burial
Temple/shrine

$\begin{array}{rr}42 & 31 \\ 13 & 10 \\ 62 & 58 \\ 16 & 13 \\ 22 & 21 \\ 12 & 11 \\ 38 & 24 \\ 6 & \\ 1 & \\ 1 & \\ 8 & \\ 4 & \end{array}$

$\begin{array}{rrr}31 & 74 & 33 \\ 10 & 77 & 25 \\ 58 & 94 & 45 \\ 13 & 81 & 1 \\ 21 & 95 & 32 \\ 11 & 92 & 1 \\ 24 & 63 & 2 \\ 6 & 100 & \\ 1 & 100 & \\ 1 & 100 \\ 7 & 88 & \\ 3 & 75\end{array}$

$\begin{array}{rrrrr}33 & 16 & 4.8 & 3.0 & 4.5 \\ 25 & 16 & 5.5 & 4.0 & 5.1 \\ 45 & 26 & 6.4 & 4.5 & 6.1 \\ 19 & 8 & 2.6 & 1.5 & 2.3 \\ 32 & 9 & 3.5 & 3.0 & 2.5 \\ 19 & 8 & 2.7 & 2.0 & 2.3 \\ 21 & 10 & 2.8 & 1.5 & 2.4 \\ 5 & 4 & 1.7 & 1.0 & 1.2 \\ 1 & 1 & 1.0 & 1.0 & - \\ 1 & 1 & 1.0 & 1.0 & - \\ 7 & 5 & 1.9 & 1.0 & 1.6 \\ 2 & 1 & 1.0 & 1.0 & 0\end{array}$

ends of this axis. The second, vertical axis explains further variation between records; again it plots records according to their (dis)similarity. The foods are plotted in similar fashion: those that frequently co-occur are plotted close together, those that do not are plotted at opposite ends of the axes. Foods and records found in the centre of the plot do not contribute much to the variation within the data set (i.e., they are found in most site types). For reasons of clarity, the records' and foods' plots are here given separately (figs. 8A and 8B). The analysis is based on the presence/absence data of each food. Included in the analysis are all waterlogged records with 5 or more foods, and all foods occurring in $10 \%$ or more of these records. Those occurring in 5$9 \%$ of records are included but down-weighted: they play a minor rôle in the analysis, but are still plotted on the graph (leaf beet, lentil, and marjoram). This resulted in a data-set of 93 records and 32 foods. For clarity, the category 'town major' has here been subdivided into provincial capital (London), coloniae (York, Lincoln, Colchester), and civitas-capitals (Silchester, Caerwent) (fig. 8A). The foods have been classified according to broad type of food (imported, wild, fruits, nuts, herbs, etc.; fig 8B).

All three methods (Tables 2-3 and 5; fig. 8) reveal the same pattern: those foods that cannot, or are unlikely to have been, grown on any scale in Britain (black pepper, sesame, date, fig, grape, olive, lentil, mulberry, cucumber, almond, peach, pomegranate, bitter vetch, and einkorn) are found primarily in major towns and on military sites. Pine nut takes a somewhat unusual position in being common in towns, but also at rural élite sites and at temples/shrines. ${ }^{1}$ Foods commonly found on rural sites are: mint, carrot, poppy seed, coriander, plum, damson, apple, cherry, celery, parsnip, and turnip (Table 2). Major towns have the highest number of new foods (26), as well as the highest average number (6.4), followed by military sites (16 and c.5 respectively; Table 5). The rural sites and the minor towns are similar to one another (Table 5), though the rural élite sites stand out with a higher overall total (32) and higher average number (3.5). Few of the minor towns, rural, and industrial sites have 5 or more foods (see average number in Table 5) and thus few of these feature on the Correspondence Analysis plot.

The Correspondence Analysis (fig. 8A) shows that the site types form quite coherent groups: the London sites in the left of the plot, the military sites mostly just above the centre, the rural sites mostly in the bottom right. There are, to date, few 'town major' records other than London (Van der Veen et al. 2007) and several of these are more closely associated with the military and rural records than with London's records. Moreover, a few rural records plot with the London ones, and some of the military extramural and intramural ones plot more closely with some rural records. The two burial records (both from London) and one of the temple/shrine records (Bath) are plotted with London's; the remaining temple/shrine record (Bunny near Nottingham) only has wild foods and is grouped with the rural records.

The foods (fig. 8B) also show remarkable coherence: the imported foods (mulberry, olive,

1 The association between pine nut and temples/shrines is well known: e.g., Kislev 1988. A full analysis of plant foods found at ceremonial sites is in preparation. 

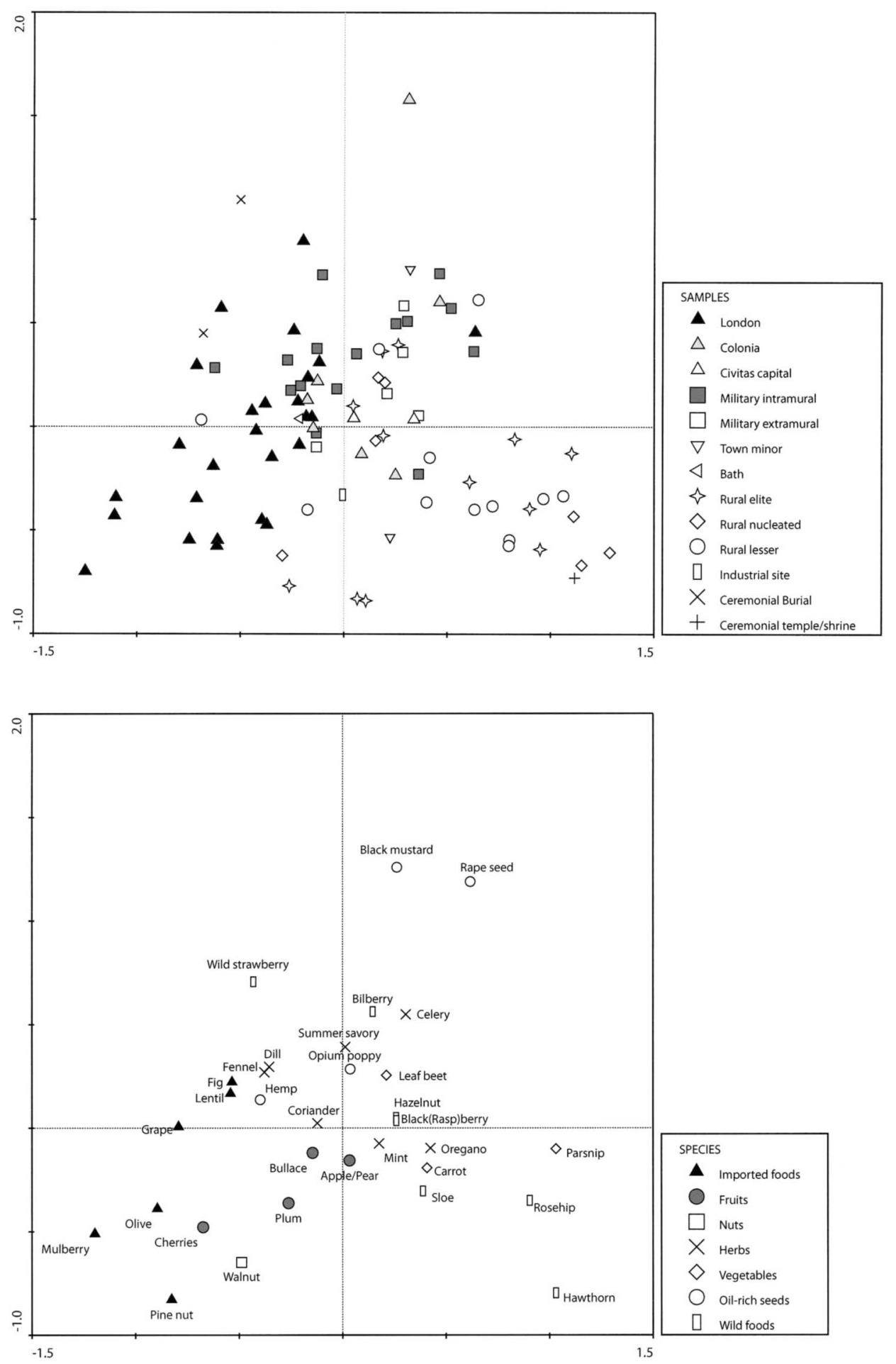

Fig. 8. Correspondence Analysis of the waterlogged records. A: plot of records; B: plot of the foods.

pine nut, grape, lentil and fig) and most of the fruits and nuts are located on the left side of the plot, the wild foods, vegetables and oil-rich seeds on the right, and the herbs just above the centre. This indicates that the major towns, and especially London, have more imported foods and more fruits and nuts, the rural sites proportionally fewer of these but more vegetables and wild foods, while the military sites have access to most foods but are particularly associated 

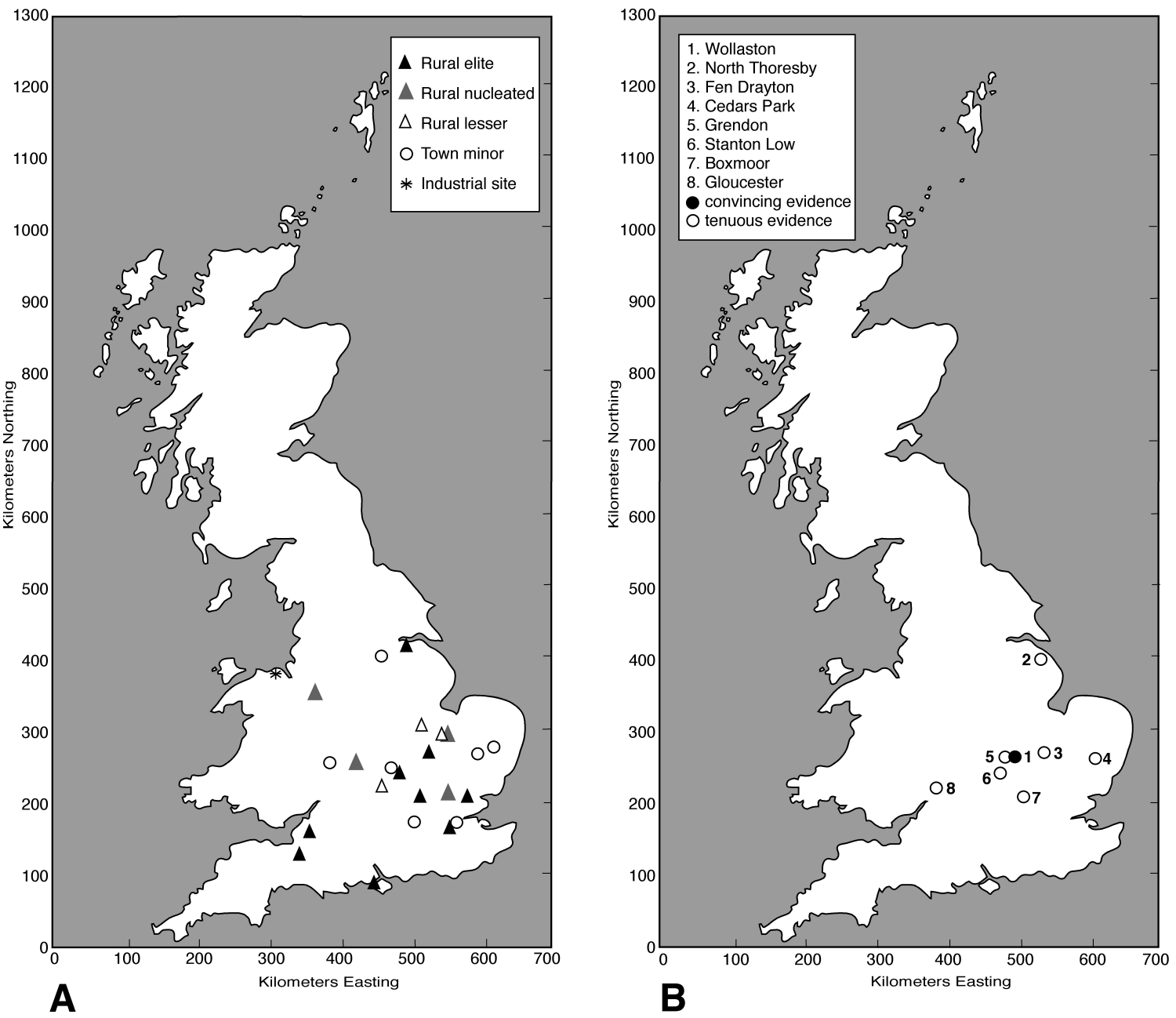

Fig. 9. A: Geographical distribution of rural records, including minor towns and industrial sites, with 'exotics' (fig, grape, olive, pine nut, lentil) (waterlogged, carbonized and mineralized preservation combined). B: Possible evidence for viticulture.

with herbs. Foods like apple/pear, damson, mint, hazelnut, black-/raspberry and coriander (plotted in the centre) do not contribute much to the variation, occurring at most types of site.

The Correspondence Analysis allows us to make some observations: 1) the rural élite (villa) sites do not form a distinct intermediate group in between the urban and (other) rural sites; 2) several small sites are grouped with the London sites: one minor town (Scole), one rural nucleated site (Tiddington), one rural lesser site (Bicester [Oxford Road]), one industrial site (Prestatyn), and one rural élite site (Great Holts Farm), as is one military extramural site (The Lanes, Carlisle). This means that they have a higher number of imported foods, fruits and nuts than their counterparts.

The various ways of looking at social access all point in the same direction: the major towns, and especially London, have the highest access to those foods that remain imports in Britain, and they have access to all other foods too. Military (especially intramural) sites similarly have access to most foods, including the many herbs, but some of them have fewer imports and fruits. The rural sites have proportionally more vegetables and wild foods, but some do have access to the imports, the herbs, and fruits and nuts, and this group includes rural élite, rural nucleated and rural lesser sites; see below for further discussion of the rural sites.

\section{Access to 'exotic' foods}

Many of the foods considered here would initially have been classified as 'exotics', in that they were unknown in Britain prior to the arrival of the Romans. Here I use the term imports or 
'exotics' for those foods that were either never cultivated in Roman Britain or only cultivated on a small scale or experimentally: figs, olives, grapes, lentils, mulberry, pine nut, date, sesame, pomegranate, almond, cucumber, millet, peach, aniseed, einkorn, and bitter vetch. ${ }^{2}$ These foods are found almost exclusively on major towns and military sites, though some people in the countryside did gain access too (figs. 7-8; Table 2). Several are present from the earliest phase of Roman occupation: there are mid-1st c. records of fig, grape and lentil from Colchester and London, as well as pine nut from Alchester; mid- to late 1st-c. records of date (Colchester), almond and pomegranate (London), and late 1st-c. records of mulberry (London), olive (Carlisle), and pine nut (London and Colchester).

In terms of regional distribution, the military have access to these foods wherever in Britain they are located. Similarly, many of the major towns have records of these foods, though the data-set is heavily biased in favour of London, due to the many excavations there (Van der Veen et al. 2007). The rural distribution of these foods is particularly noteworthy (fig. 9A): there are relatively few records and all are concentrated in the southeast (see figs. 1C and 1D for the rural distribution of all archaeobotanical records). Four of these records are from rural lesser sites, including a 1st-c. record of fig and grape from Bicester [Oxford Rd.] and 1st- or 2nd-c. lentils from Maxey (Cambs.). Fig and grape of the 1st c. were also recovered from the villa at Gorhambury, but as this site is part of the Verulamium complex it may not strictly classify as 'rural'. These expensive foods clearly reached the countryside right from the start of the Roman occupation, increasing over the course of the Roman period, but access remained exclusive, though was not restricted to rural élite sites.

There is evidence that attempts were made to cultivate grapes in Britain. Possible remains of vineyards have been found at 8 locations (fig. 9 B; for references see Brown et al. 2001, Williams 1977, and Nicholson 2007 for Cedars Park). The most convincing case is at Wollaston in the Nene valley. Here a complex of parallel trenches was discovered, with stakeholes suggestive of a pastinatio-type vineyard. Pollen analysis of deposits from these trenches found low but consistent frequencies of grape (Vitis) pollen (Brown et al. 2001). Such a large vineyard must have represented a major financial and economic investment. Surprisingly, it was found close to a number of rural lesser sites, but there is a small villa nearby. It has not yet been ascertained how successful these vineyards were and whether they were intended for the production of wine or grapes.

\section{Rural access to the new foods}

The rural distribution of the other new foods also merits further consideration (figs. 10-11). Mint and coriander are the most common herbs on rural sites, with mint reaching $29 \%$ and coriander $21 \%$ by the Middle Roman period; coriander increases to $24 \%$ by the Late Roman period (fig. 10). While the seeds of coriander do travel well and may thus have been imported, it is generally assumed (e.g., Robinson 2006, 208) that the presence of coriander at rural sites in Britain is indicative of local cultivation. Rural records with herbs are found exclusively in SE England (fig. 11), though they are more numerous than those with 'exotic' foods (fig. 9 A) and comprise all types of rural site, including minor towns and industrial sites (coriander at Prestatyn, celery at Morton Fen). There is no indication that their availability started at élite sites and moved over time to rural lesser sites. The earliest records are late 1st-c. coriander at Faccenda Farm and Bicester [Oxford Rd.] (rural lesser sites), and late 1st- to 2nd-c. fennel and coriander at Tiddington (rural nucleated), but the number of records increases towards the Late Roman period.

Of the fruits and nuts (apple/pear, cherry, plum, damson and walnut), apple/pear is the most common, but all increase over time (most reach $15 \%$ of rural sites by the Late Roman period; only apple/pear is more common at $29 \%$ ). Their distribution on rural sites is wider than that of herbs and includes a larger number of non-élite sites, with several outside the south-

2 Wine and olive oil were widely imported to Britain, as witnessed by the many sherds of amphorae. Similarly, the import of peaches, dates, and other fruits can be traced via the characteristic amphorae used to transport those. A comparison of the two types of evidence is outside the scope of this paper (but see Cool 2006). 

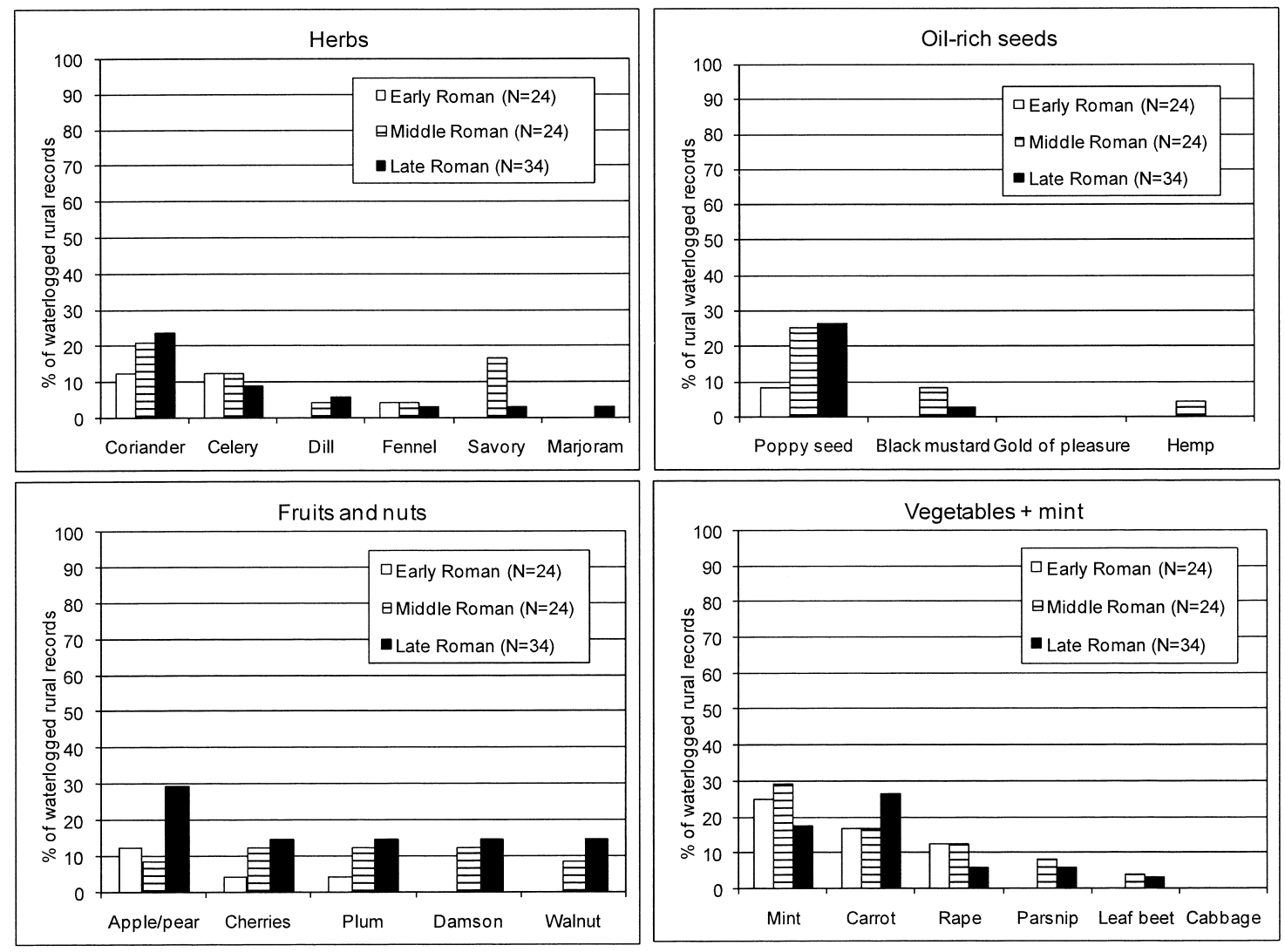

Fig. 10. Ubiquity of foods in the rural records, including minor towns and industrial sites (waterlogged records only), expressed as the proportion of records with each food, by phase.

east. Cherry and plum are present from the 1st c. onwards, while walnut and damson occur on rural sites from the start of the 2 nd c.; walnut tends to be more common on élite sites. There is a strong increase over time (fig. 10).

Carrot and turnip are the most commonly encountered vegetables; carrot increases over time, turnip decreases slightly. Cabbage has not yet been found on rural sites. Parsnip and leaf beet occur from the mid-Roman period onwards. These vegetables are rarely found in the archaeological record, primarily because the leaves and roots, rather than the seeds, are eaten. Moreover, their seeds are morphologically difficult to distinguish from those of the wild species, making the archaeological record difficult to interpret (they could represent wild plants). ${ }^{3}$ However, the marked increase of these plants from the Iron Age to the Roman period (see below) suggests that these food plants were increasingly being cultivated. The distribution of rural sites with one or more of these vegetables is slightly wider than that of the preceding food groups. Finally, oil seeds (primarily poppy seeds) become common and increase considerably over time, though their distribution remains restricted. The impact of these new introductions on the productive economy is discussed below.

\section{Consumption of wild fruits and nuts}

Several wild food plants occur commonly in the botanical assemblages, especially elder-

While cabbage and leaf beet are almost certainly cultivated vegetables (especially when found at inland sites; M. Robinson, pers. comm.), this is less certain in the case of carrot and parsnip. The records of the latter two could represent wild forms without edible roots. The Romans did know cultivated carrot (a white variety) and parsnip, though confusion over the names exists (Andrews 1949 and 1958; Giacosa 1992). The large fleshy root forms we know today were developed much later (the familiar orange carrot not until the 17th c.: Vaughan and Geissler 1997). 
Diversity and change in plant food consumption in Roman Britain 99
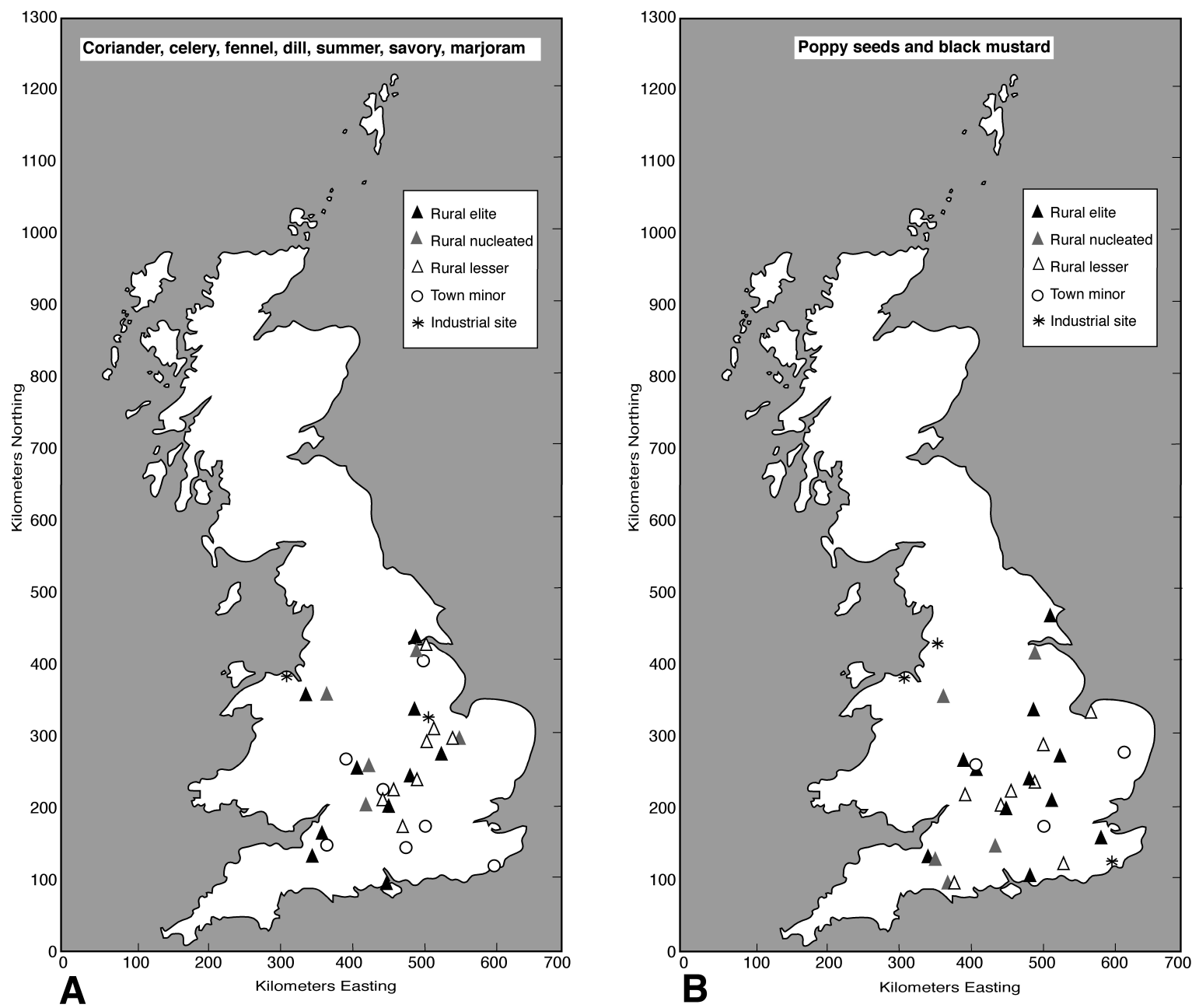

Fig. 11 A-B. Geographical distribution of rural records, including minor towns and industrial sites, with specific foods (waterlogged, carbonized and mineralized preservation combined). A: herbs; B: oil-rich seeds.

TABLE 6

\section{OCCURRENCE OF SELECTED FOODS IN IRON AGE AND ROMAN RECORDS,} ALL MODES OF PRESERVATION

N.B. for the Roman period only rural records are included to provide direct comparison with the Iron Age data. Iron Age data taken from the ABCD and supplied by A. Hall (cf. supra n.4)

\begin{tabular}{|c|c|c|c|c|c|c|c|c|c|}
\hline \multicolumn{5}{|c|}{$\begin{array}{r}\text { Iron Age } \\
\text { all sites ruan } \\
\text { records } \\
\text { only }\end{array}$} & \multicolumn{5}{|c|}{$\begin{array}{r}\text { Iron Age } \\
\text { all sites rural } \\
\text { records } \\
\text { only }\end{array}$} \\
\hline $\mathrm{N}$. & 162 & 337 & $\%$ Iron Age & $\%$ Roman & N. & 162 & 337 & $\%$ Iron Age & $\%$ Roman \\
\hline Hazelnut & 38 & 106 & 23.5 & 31.5 & Parsnip & 2 & 6 & 1.2 & 1.8 \\
\hline Black/raspberry & 20 & 58 & 12.3 & 17.2 & Apple/Pear & 2 & 19 & 1.2 & 5.6 \\
\hline Elderberry & 17 & 62 & 10.5 & 18.4 & Dewberry & 2 & 2 & 1.2 & 0.6 \\
\hline Sloe & 10 & 39 & 6.2 & 11.6 & Wild strawberry & 1 & 6 & 0.6 & 1.8 \\
\hline Hawthorn & 7 & 32 & 4.3 & 9.5 & Cherries & 1 & 10 & 0.6 & 3.0 \\
\hline Rosehip & 7 & 24 & 4.3 & 7.1 & Rowan & 1 & 1 & 0.6 & 0.3 \\
\hline Crowberry & 5 & 1 & 3.1 & 0.3 & Bilberry & 1 & 3 & 0.6 & 0.9 \\
\hline Carrot & 4 & 21 & 2.5 & 6.2 & Celery & 0 & 8 & 0.0 & 2.4 \\
\hline & & & & & Marjoram & 0 & 1 & 0.0 & 0.3 \\
\hline
\end{tabular}



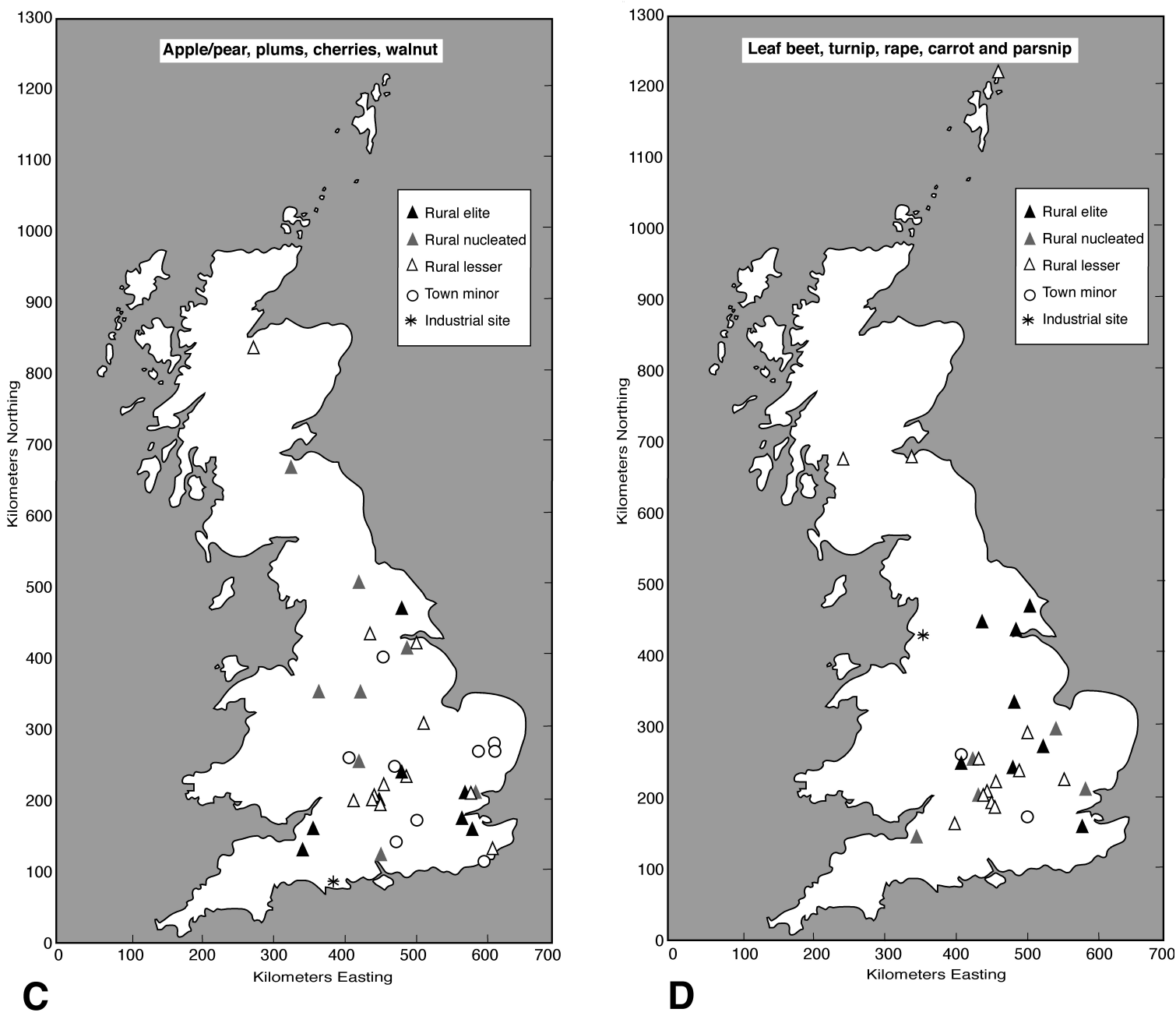

Fig. 11 C-D. Geographical distribution of rural records, including minor towns and industrial sites, with specific foods (waterlogged, carbonized \& mineralized preservation combined). C: fruits \& nuts; D: vegetables.

berry, black-/raspberry, hazelnut, sloe, hawthorn, wild strawberry, rosehip, and bilberry (Table 4; fig. 12), though, as mentioned above, the seeds of elderberry, blackberry and hawthorn need not represent food remains (these plants are commonly found in wasteland near settlements). The occurrence of wild foods on Roman sites is considerably higher than on Iron Age sites (Table 6). ${ }^{4}$ This cannot be explained by taphonomic factors as the data for each period are comparable: the percentage of Iron Age waterlogged sites lies somewhere between 17 and $25 \%$ (mode of preservation not always recorded); that from all Roman rural records is $21 \%$. While hazelnut occurs on a quarter of Iron Age sites, and black-/raspberry and sloe on $c .10 \%$ of sites, no other wild foods appear to have been regularly consumed (only two occurrences of wild apple seeds have been recorded for Iron Age sites in Britain). A similar pattern is seen in faunal assemblages: bones of wild animals, including freshwater and marine fish, are rarely recorded on Iron Age sites. This suggests that wild foods in general were subject to prohibitions. In the few instances in which wild animal bones have been found, these appear to be linked to ritual behaviour (Grant 1984; Hill 1995b; Jones 1996; Dobney and Ervynck 2006).

4 The collection of data from Iron Age sites was outside the scope of this project, but A. Hall kindly supplied the data given in Table 6, taken from his most recent version of the ArchaeoBotanical Computer Database (Tomlinson and Hall 1996). While the method of recording in the ABCD is not identical to that used in this project, the figures identify a change in use over time. 


\section{Diversity and change in plant food consumption in Roman Britain 101}
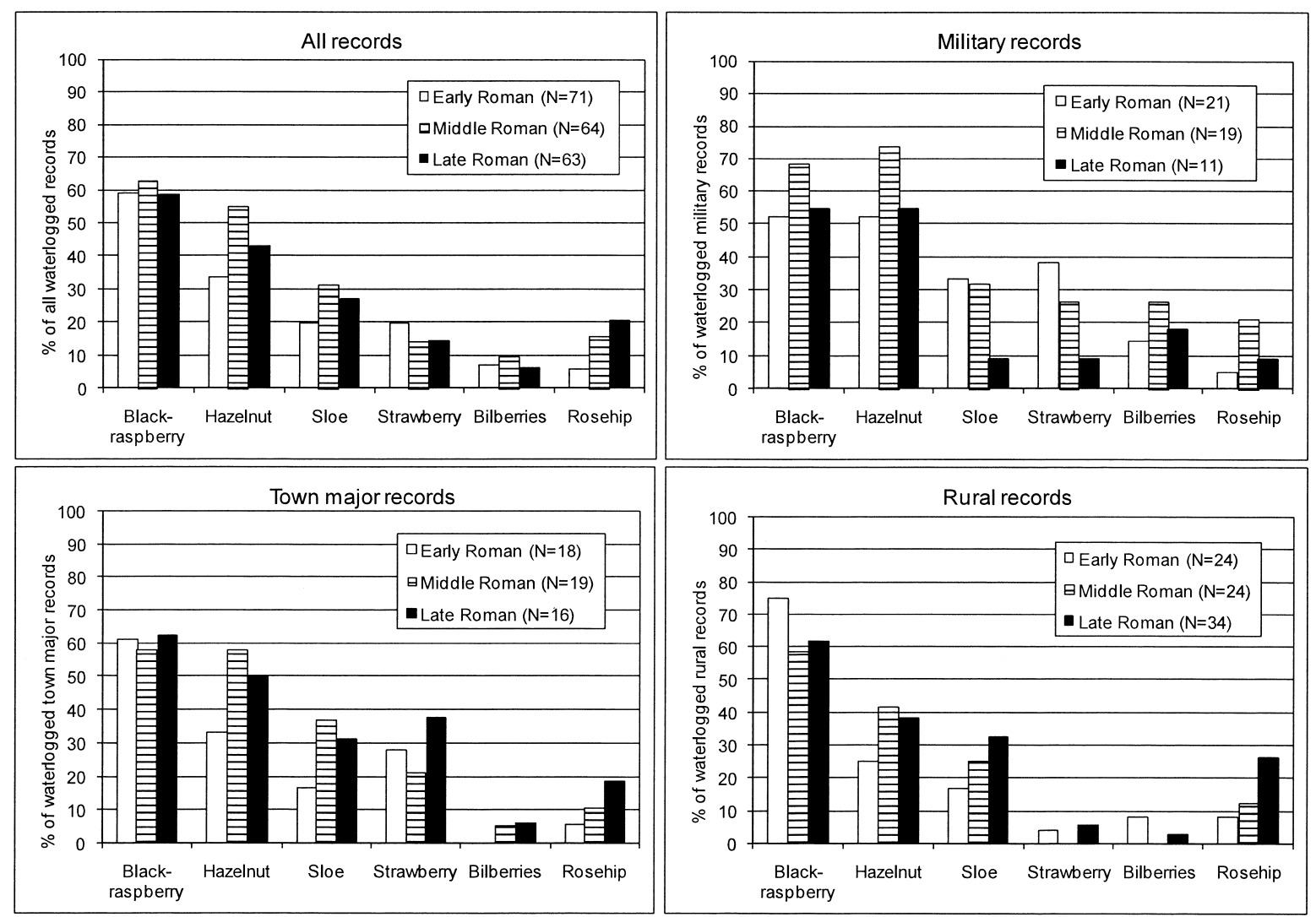

Fig. 12. Ubiquity of the wild foods by phase (waterlogged records only), expressed as the proportion of records with each food, by site category. Rural group includes minor towns and industrial sites.

The consumption of wild plant foods in Roman Britain is not only widespread, but also increases in abundance during the course of the Roman period; this is especially the case with hazelnut, sloe, and rosehip. Moreover, consumption of these foods is high at all types of site (fig. 12) and not restricted to the countryside. For example, the consumption of hazelnut in major towns goes up from 32\% in the Early Roman to 55\% in the mid-Roman period. The consumption of sloe also goes up in major towns, while black-/raspberry is very common and wild strawberry more common in the major towns than in the countryside. Their geographical distribution is broad, with records found across the country, though rowan has a distribution in NW Britain.

\section{Discussion}

\section{Changing foodways}

These new foods represent the first serious diversification of the plant component of the British diet since the introduction of wheat and barley during the Neolithic. Prior to the Roman invasion, the British diet, in terms of plant foods, had consisted of a limited range of staples (wheat, barley, peas and beans), an oil-crop (linseed), and a restricted number of wild foods (mainly hazelnut). While the consumption of wild greens - the leaves of dandelion, docks, fat hen, and others - is likely, and nutritionally important, we have no direct evidence for this. Even though this limited dietary range was extended during the Late Iron Age (see above), it is not until the Roman period that we see the introduction of some 50 new food plants, as well as a renewed interest in wild fruits. This represents a tremendous increase in the range of nutrients, flavours, textures, as well as opportunities for display of wealth. While some foods remained rare imports (e.g., dates, black pepper, sesame), many became commonly available in certain parts of the country and to certain groups of individuals. 
The new foods offered a significant broadening of the range of vitamins, minerals and fatty acids available through plant foods, and thus embody a major improvement of the nutritional value of the diet. Simultaneously, the wide range of new foods, especially the condiments, offered new ways of preparing and flavouring foods, including the ability to spice up the basic staples such as porridge, bean stews, and bread. Herbs and spices in particular represent a switch to a more Roman form of cuisine: they formed an important ingredient in sauces that accompanied meat, fish and vegetable dishes, together with wine, reduced must, fish sauce, and olive oil; nuts and prunes were sometimes added too (Giacosa 1992, 27). The number of ingredients in these dishes was often large compared to today, 10-13 ingredients being quite common (Alcock 1993). Poppy seeds and herbs such as aniseed, fennel and celery were also used to flavour breads and cakes; poppy seeds sprinkled on loaves of bread offered additional nourishment (protein) (Alcock 1993, 19). Pine nuts, walnuts and almonds, as well as poppy seeds, were also added to milky puddings, and cumin and honey were used in baked egg dishes (patina), together with fruits such as peaches and pears (Giacosa 1992, 172).

Many of the herbs and spices, as well as vegetables and fruits, were also widely used as medicinal plants. Concoctions to aid digestion and for an upset stomach consisted of mixtures of herbs, spices, fruits, together with honey and vinegar (Giacosa 1992, 178). Note also that, while today rue is often regarded a medicinal plant, it was a common ingredient in Apicius' recipes (Giacosa 1992).

With the introduction of so many new fruits, vegetables and nuts, the popularity of native wild fruits and nuts was expected to have declined, but the opposite appears to have been the case: the consumption of wild plant foods appears to be re-established, overturning a possible taboo of such foods during the Iron Age, and to have increased during the Roman period. Remarkably, the introduced foods did not replace the native wild foods: rather, their introduction may have encouraged the consumption of wild fruits and nuts, and on all types of site (rural and urban). This meant that people in the countryside without access to the new (introduced) foods still gained some new foods and flavours in the form of the wild foods.

While the focus of this paper is the plant foods themselves, brief mention must be made of the fact that changes also occurred in the way food was prepared and consumed. Shifts in the composition of the ceramic assemblages found at Late Iron Age and especially Roman-period settlements highlight a move from communal eating (jars and deep bowls) to the serving of more individual portions (platters and cups) (Cool 2006 chapt. 16; Hill 2002; Pitts 2005), suggesting significant changes in social practice (Of course, this evidence may also be interpreted as an increase in the number of separate dishes and courses served at each meal.)

Within a very short period of time, we see a major shift in who ate what and how. During the Iron Age, British cuisine was mostly undifferentiated: everyone, including those in higher social positions, ate the same small range of staple foods. Special feasts were characterized more by the quantity of the food consumed (especially of meat) than by its quality or exotic origin (Goody 1982: his "low cuisine"; see also Van der Veen 2003; 2007). During the Late Iron Age, the few imported foods that reached SE England were primarily display items for a few wealthy individuals. Immediately after the conquest, a much wider range of foods was imported and became available to a much larger section of the British population; they are no longer found just in graves but in a variety of occupation layers. While this suggests a shift from Goody's 'low' to his 'high' cuisine, this research, amongst others, highlights that the situation is far more complex than this simple dichotomy suggests. Marked regional differences in who eats what emerge during this time, and variations within types of settlement also develop. The relatively rapid spread of the new foods across southern Britain may partly be explained by emulation, the adoption of aspects of superior Roman culture by the local élite in order to belong to the new political order, though other explanations can be envisaged too (see below).

\section{Emergence of horticulture}

Another significant development is the emergence of horticulture (i.e., the cultivation of fruits, vegetables, and herbs in small garden plots and/or orchards). Prior to the Roman period, British agriculture was focused on cereal cultivation along with some pulses and oil seeds. 


\section{Diversity and change in plant food consumption in Roman Britain 103}

While the size of fields and intensity of cultivation in some areas may have resembled garden plots, horticulture per se did not exist. Many of the new foods (initially they were imports) could be cultivated in Britain, and this appears to have happened relatively quickly. Some of this production will have been for personal consumption, but much will have been used to meet the demand of urban inhabitants.

Horticulture is characterized by being very labour-intensive, requiring both regular input of labour and manure. Much of the produce is also seasonal, perishable, and not easily stored for long periods of time or transported over long distances. Consequently, 'commercial' horticulture (as against growing a few vegetables for private use) is usually found located close to centres of population and/or on easy transport routes; it also tends to be associated with societies with substantial groups of people not engaged in food production (hierarchical societies).

Possible examples of horticultural plots are the linear cultivation beds found at Culver Street, Colchester (cautiously interpreted as a suburban market garden or allotment: Crummy 1984, Murphy and Scaife 1991), and planting pits found in association with the villa at Ditchley (Applebaum 1972) and within the walls of Wroxeter (Wacher 1975) (for both, see Jones 1991). Such garden plots are exceptionally difficult to identify in the archaeological record, but Taylor (2007) has noted that, unlike Iron Age sites, many rural Roman sites are characterized by the presence of small plots - i.e., segregated spaces attached to a settlement (enclosure complexes rather than enclosed settlements). These small plots or paddocks could have been used for a few animals, vegetables and herbs, a small orchard, and so on. A systematic survey of such plots would be beneficial. Definite rural examples of horticultural plots are not known, though the plots and parallel ditches sometimes interpreted as evidence for viticulture (fig. 9b) may, of course, have had a more general horticultural function.

There is also evidence for gardening at military sites: on Hadrian's Wall at Wallsend and Housesteads (Griffith 1993), on the Antonine Wall at Croy Hill (Goodburn 1978) and Rough Castle (Máté 1995), and possibly at Moresby in Cumbria (Grew 1981). Small and often irregular plots, sometimes defined by shallow gullies, which are suggestive of allotments or small garden plots, have been found, usually outside the walls of the fort; they will have been tended by the soldiers or inhabitants of the vicus. This is corroborated by the presence of iron spades and pruning hooks (tools associated with vegetable and fruit cultivation) at military sites (Rees 1979). This evidence suggests that the military satisfied their demand for fresh produce by growing it themselves (or purchasing it from residents of the vici). If so, this will have disadvantaged the local rural population outside the vici, removing an opportunity for them to cash in on what might have been a lucrative market.

While horticulture includes the cultivation of both annual seed crops (such as vegetables and herbs) and tree crops (such as fruits and nuts), the investment needed to start cultivating these two types of crop differs. Vegetables and herbs (like cereals and pulses) require a small investment: access to seeds, some land, manure, labour, and some understanding of how crops grow. The cultivation of fruit trees entails a much larger initial investment; it also demands more technical know-how as well as time. Fruit trees such as apple, pear, cherry, and plum start yielding fruit only after 5-10 years, representing a considerable delay in return on investment.

Technically, fruits and nuts are also more difficult to propagate. The plants are heterozygous and cannot successfully be propagated using sexual reproduction (from seed): they need vegetative reproduction. While grapes, figs, olives, pomegranates, and dates (all fruits domesticated early in the Near East) can be multiplied by cuttings, rooting of basal knobs or by transplanting offshoots, the temperate fruit trees such as apple, pear, plum and cherry tend to be propagated using the more complex technique of grafting. Current evidence suggests that these trees were all domesticated relatively late (Zohary and Hopf 1994, 135-37). It is not known exactly where and when the technique was 'invented', but it is believed to have occurred east of the Mediterranean, possibly in China. The technique was known by the classical period and described by Theophrastus, Cato, and Columella (White 1970, 248-58). The introduction of the technique into NW Europe is widely assumed to date to the Roman period (Zohary and Hopf 1994, 135-37), though this can be demonstrated conclusively only through future DNA analyses. 
The first such evidence is now available for the domestic apple. While the wild crab apple (Malus sylvestris) is native to Britain and NW Europe, recent DNA analysis has now identified Malus sieversii, native to the mountains of Kyrgyzstan and NW China, not Malus sylvestris, as the wild progenitor of our domestic apple (Harris et al. 2002). It is thus highly likely that the Romans introduced the domestic apple to Britain, though only DNA analyses on archaeological apple pips can confirm this. The introduction of cultivated pear, plums and walnut is not in doubt as none of their potential wild progenitors is native to Britain. The position of cherry is uncertain.

The introduction of cultivated trees into Britain would have required the import of budded stems (scions), which could be grafted on to local rootstock (wild crab apple, sloe, etc.) that was specially developed for the purpose, or by bringing in the rootstock (the live plant). Evidence for the transport of live plants is available in the form of ollae perforatae, purpose-made pots to plant and transport trees, vines and shrubs (Macauley Lewis 2006), which are found across the empire, including Britain, and date to the late 1st c. B.C. to mid-2nd c. A.D. To date, no plant pots of definitive foreign origin have been identified in Roman Britain, but more work is required.

Large-scale fruit and nut cultivation tends to be initiated only by individuals who can afford the initial outlay, and then only if sufficient demand for the produce has been identified. Fruit cultivation may have started on a small scale; perhaps some retired soldiers or immigrants from Italy or Gaul had a few fruit trees brought over for their private gardens; later, further grafting of those specimens may have been done for 'commercial' orchards. A systematic review of rural sites with evidence for financially demanding investments, including fruit cultivation, would be illuminating. That these fruits became available in quantity is clear not just from fig. 11c, but also from the hundreds of apple pips ${ }^{5}$ found at 2nd-c. Doncaster [Frenchgate] (Buckland and Magilton 1986, 198), London, and Late Roman Silchester (Robinson 2006).

The evidence for horticultural production on rural sites is currently restricted to the $\mathrm{S}$ and $\mathrm{E}$ parts of the country (figs. 9B and 11). This coincides with the known distribution of towns in Roman Britain, and the two are likely to be linked. It was the townspeople who probably formed the largest 'market' for these foodstuffs (much horticulture will have taken place within the towns themselves); it was in connection with towns too that the best transport routes existed, with rivers and roads frequented by traders carrying goods under contract. This is also the part of Britain that has seen the most archaeobotanical work (Van der Veen et al. 2007), but other evidence for rural development and prosperity (villas, corn-driers, large barns, etc.) have a similar distribution in SE Britain (Jones and Mattingly 1993, maps 6.46 and 7.6; Taylor 2007, figs. 4.9 and 7.3). As the latter evidence does not suffer the complex taphonomic biases that afflict botanical remains, it would appear safe to conclude that the development of horticulture was centred on central, southern and eastern Britain, the area where demand, transport facilities, and prosperity coincided.

Diversity and change

It is clear from the results presented above that the traditional opposition of Romans versus Britons, as used in the 'Romanization' paradigm, does not provide an adequate or appropriate framework for studying the diverse responses to the new foods. On the basis of the botanical evidence alone, we can identify several consumer groups, as well as strong regional variation, and changes over the span of the Roman occupation. This matches the conclusions reached by Cool (2006), Grant (2004), King (1999) and Mattingly (2006), who also highlighted the varied regional and chronological experiences and practices based on different types of material culture. There was no one 'Roman' cuisine, no one 'Roman' Britain, no one 'urban' or 'rural' pattern.

In terms of consumer groups, London stands out as a community with access to probably the highest number of new foods, especially those that remained imports and/or rare throughout the Roman period; this highlights its special position as the main trading centre with a large 


\section{Diversity and change in plant food consumption in Roman Britain 105}

immigrant population (Millett 1990, 89; Mattingly 2006, 511; Creighton 2006, 93-107). Its metropolitan character, its social mix of people, and in many cases their temporary residence, may have encouraged the need for markers of identity and status (Creighton, ibid), such as imported foodstuffs. The other major towns had similar consumption patterns to London although, to judge from current evidence (though this may be a sampling issue), more limited access to the rare foods.

The minor towns were very different. With one or two exceptions, they had access to fewer new foods and, in terms of food consumption, resemble the rural nucleated and rural lesser sites, rather than the major towns. H. Eckardt (2005) and S. Willis (2005) reached similar conclusions based on their analyses of nail-cleaners and Samian ware, respectively. For this reason, the minor towns were added to the rural distribution maps (figs. 9 and 11).

The military sites form a fairly distinct group, with access to many of the new foods and, in particular, a high proportion of herbs and oil-rich seeds. The abundance of herbs especially points to the adoption of aspects of a Roman cuisine. This contrasts with the findings of A. King (1999) that, in terms of meat consumption, the military in Britain followed a more Gallic/ Germanic pattern, consuming more beef and mutton than was customary in the core of the empire. Interestingly, the average number of new foods in the extramural settlements is a little higher than in the intramural ones (Table 5), which suggests a broader social group and a slightly wider range of food activities here, including trade and élite consumption (soldiers visiting), as well as cultivation of vegetables.

The next identifiable group of consumers is that of a select group of country-dwellers in SE England that had access to many of the new foods, including some of the 'exotics': figs, grapes, pine nuts, and lentils. This consumer group did not consist exclusively of élite sites, but rather was made up of residents of villas, nucleated sites, and small farmsteads, as well as minor towns. A further rural group, again comprising non-élite and élite sites in SE England, had access to a selection of the new foods, especially temperate fruits and vegetables: apple, pear, plums, cherry, turnip, leaf beet, parsnip, carrot - that is, mostly foods that became incorporated into British agriculture soon after the conquest. In view of the lack of waterlogged preservation at most rural sites and the consequent under-representation of these foods at rural sites, this group is likely to have been much larger than our records imply. Finally, there are those who did not participate in the new foodways, even though many of them did start eating the native wild foods, thus acquiring some variety of flavours and nutrients: they include residents of some villas, nucleated sites, rural lesser sites and minor towns (and doubtless many residents of the major towns). This group included some people living in the SE and central parts of the country and most or all of those living in the $\mathrm{N}$ and $\mathrm{W}$ parts, including all of Scotland. Thus, while most in Britain will have been aware of the many new foodstuffs, few had the means or inclination to try them.

While the relative lack of archaeobotanical work in $\mathrm{N}$ and $\mathrm{W}$ Britain must affect our data, there appears to be a real and marked regionalisation in the uptake of Roman foodways, the centre of this uptake being located in central and SE England. This matches the distribution of other markers of Roman culture and economic prosperity, such as architectural styles, ceramics, clothing, personal ornament, and increasing agricultural production, suggesting that this distribution is not an artefact of selective sampling or preservation.

Reasons for the selective uptake of aspects of Roman culture will have been complex and diverse (Mattingly 2004). Evidence of a Roman cuisine in the major towns and villas may reflect either the presence of individuals of Mediterranean origin or the adoption of Roman foodways by the local urban and rural élite in order to 'be Roman'. The presence of some of the new foods, and especially the 'exotics', at rural non-élite sites is more difficult to interpret. Does this evidence signify that the residents had achieved élite status, or merely that they aspired it? A study of other forms of material culture at such sites may help distinguish between the two. The presence of the temperate fruits and vegetables may denote the grasping of economic opportunity rather than emulation, as well as signify that these foods were also enjoyable to eat and 
nutritionally important. ${ }^{6}$ Reasons for the lack of uptake in $\mathrm{N}$ and $\mathrm{W}$ Britain are more difficult to determine, but they will have included both lack of opportunity and lack of desire. The dearth of detailed archaeobotanical work in this region hampers any synthesis, although the consensus is that the heavy military presence may have hindered economic expansion (Mattingly 2006,174). If vici took on the rôle of supplying the military garrisons with vegetables (and fruits?); this could have thwarted the development of horticulture in the north and west.

These new foodways were not static: the popularity of the new foods changed over the span of the Roman occupation. Many of the typical Mediterranean foods (figs, grapes, lentils, mulberries, pine nuts, also fennel) declined in frequency over time. This matches the patterns for other Mediterranean imports: during the 3rd c., the import of wine, olive oil and fish products from the Mediterranean (as reflected by amphorae) declined, probably as a result of structural changes in the empire's economy, interruptions in the supply, a reduction in the size of the British garrison and changes in its manning (Fulford 2004; Mattingly 2006, 514; Millett 1992, 162-73 with Table 6.2). Wine may have been partially substituted by imports in wooden barrels from the Rhineland, but other foods were replaced where possible by local manufacture (Fulford 2004). The decline in exotic plant foods fits this pattern, though the supply does not cease, as is sometimes implied from the ceramic evidence (Fulford 2004). The common occurrence of figs, as well as the presence of mulberry, pine nut and olive in London and elsewhere, indicates that some supplies still came through even as late as the 4th/early 5th c. (e.g., fig and lentil from Late Roman Silchester: Robinson 2006).

Not all changes in availability can be attributed to external factors affecting trade. The rise and subsequent decline in the herbs may relate more to changing food preferences and a reduction of those aspiring to eat 'Roman' foods; after all, many of the herbs were probably produced locally by the late 2 nd c. The taste for Mediterranean-style foods may have declined from the 3rd c. as the British garrison was reduced in size and had fewer troops of Mediterranean origin (Millett 1992, 163; Mattingly 2006, 501). The increase in coriander, poppy seeds and, to a lesser extent, grape in Late Roman times at rural sites in SE England is noteworthy in this respect; while it appears to go against the trend, it can be explained by the move of the élite to the countryside and the associated rise of the villas as élite rural settlements displaying aspects of Roman culture.

It is worth noting that the rural distribution of the temperate fruits and vegetables appears slightly less restricted geographically than that of herbs and poppy seeds (fig. 11). This may confirm that the latter were more closely associated with Roman foodways than the former. The temperate fruits and vegetables are less likely to represent simply emulation of Roman culture: they become fully incorporated into British agriculture and cuisine, whereas herbs such as coriander decline rapidly after the Roman period (Livarda and Van der Veen 2008).

\section{Conclusions}

This review has highlighted significant changes in both food consumption and production in Britain during the Roman period. The arrival of some 50 new food plants around this time resulted in a broadening of the diet, bringing essential nutrients, variety of flavours and dishes, as well as new opportunities for the acquisition of wealth and display. That these foods were used in the creation and maintenance of identity is clear from the various consumer groups who could be identified. Some individuals and groups were able to take advantage of the new foods, while others either could not or chose not to. London stands out as the place with the highest access to the new foods, including many of the rare ones, followed by the military settlements and the other major towns. At rural sites, there is a marked regional pattern with only those located in the central and SE parts of the country gaining access to the new foods, matching other evidence of agricultural development and wealth accumulation; but within this region there are marked differences between sites that gain access and those that do not - which may

6 The emphasis on certain foods as simply the consumption of signs fails to recognize that luxury foods are often nice to eat (Dietler 2007; Berry 1994; Van der Veen 2003). 


\section{Diversity and change in plant food consumption in Roman Britain 107}

partly be due to sampling and preservation biases, but may also reflect genuine differences in the degree of aspiration, economic opportunity and success in 'becoming Roman'. More detailed analyses, based on all types of material culture, of rural lesser sites with access to the 'élite' foods, and of élite settlements with no evidence of these foods, will be beneficial. Lastly, the rural occupants of a large part of the country either did not desire the new foods or was not able to access them.

The new foods reached all categories of site (urban, military and rural) soon after the conquest, though in the countryside in particular the increase in adoption of these foods dates to the later Roman period, reflecting the flourishing of rural villas at that time. Other marked chronological changes are the overall decline in certain foods over the period, and the rise and subsequent decline of others; the foods associated with these two patterns are those most clearly linked to Roman culture. A third group, the temperate fruits and vegetables, shows evidence of an increase over time. These foods also had a slightly wider rural distribution than the other foods, had a more significant impact on the agricultural economy with the introduction of horticulture, and ultimately became fully integrated into the British productive economy. While many aspects of Roman culture, including many foods, disappeared during the 5th c., at the same time that the small élite that had access to them declined or disappeared, some foods did not, highlighting their connection to a wider group and to the economic, rather than the strictly social, structure of society.

Marked diversity and change in plant food consumption has been identified, demonstrating how archaeobotanical data, like other forms of material culture, can make a significant contribution to our understanding of Britain and other provinces. A study of foodstuffs through their connection with the individual, the social group, and the productive economy can enhance the archaeological and historical narrative of the Roman empire.

mvdv1@leicester.ac.uk School of Archaeology \& Ancient History, University of Leicester

\section{Acknowledgements}

This project could not have been completed without the help of very many institutions and individuals. I would like to thank the University of Leicester and the Arts and Humanities Research Council for the research leave during which this project was completed, and the British Academy and Natural Environment Research Council for grants that funded the bibliographical searches and data collection. Many thanks are due to Alexandra Livarda, who constructed the database and completed a substantial part of the data recording, and to Alistair Hill, who helped with the bibliographic research and the data recording. Allan Hall generously provided an updated version of the ArchaeoBotanical Computer Database, and Neil Christie, Simon James, and especially David Mattingly and Jeremy Taylor assisted in the classification and phasing of sites, and commented on early stages of the data analysis. Alex Moseley, Niven Moledina and Dimitros Koulkoulis kindly helped with the construction of the Access database. Figures 1, 9 and 11 were drawn by Debbie Miles-Williams. I am very grateful to Allan Hall, Catherine Johns, David Mattingly, Martin Millet, Jeremy Taylor and Richard Thomas for helpful comments on earlier drafts of this paper.

Many colleagues have helped by sending references, copies of 'grey' literature and/or their unpublished data: Paul Booth, Gill Campbell, Wendy Carruthers, Astrid Caseldine, Mike Charles, Marina Ciaraldi, John Giorgi, James Greig, Lisa Gray, Allan Hall, Tim Holden, Jacqui Huntley, Jennifer Miller, Lisa Moffett, Angela Monckton, Peter Murphy, Ruth Pelling, Mark Robinson, Vanessa Straker, and Scott Timpany. Alison Cox and Jacob Morales helped with the acquisition of the reports.

\section{References}

Alcock, J. P. 1993. "Flavourings in Roman culinary taste with some reference to the province of Britain," in H. Walker (ed.), Spicing up the palate: studies in flavourings - ancient and modern (London) 11-22.

Andrews, A. C. 1949. "The carrot as a food in the classical era," CPh 44, 182-96.

Andrews, A. C. 1958. "The parsnip as a food in the classical era," CPh 53, 145-52.

Applebaum, S. 1972. "Roman Britain," in H. P. R. Finberg (ed.), The agrarian history of England and Wales 1

(ii) (Cambridge) 1-277.

Berry, C. J. 1994. The idea of luxury: a conceptual and historical investigation (Cambridge).

Bowman, A. K. 2003. Life and letters in the Roman frontier. Vindolanda and its people (London).

Brown, A. G. et al. 2001. "Roman vineyards in Britain: stratigraphic and palynological data from Wollaston in the Nene Valley," Antiquity 75, 275-87. 
Buckland, P. C. and J. R. Magilton 1986. The archaeology of Doncaster, vol. 1. The Roman civil settlement (BAR 148, Oxford).

Cool, H. E. M. 2006. Eating and drinking in Roman Britain (Cambridge).

Creighton, J. 2006. Britannia. The creation of a Roman province (London).

Crummy, P. 1984. Excavations at Lion Walk, Balkerne Lane, and Middlebrough, Colchester, Essex (Colchester Archaeological Report 3).

Cunliffe, B. 2000. The Danebury environs programme. The prehistory of a Wessex landscape, vol. 1. Introduction (OUCA Monog. 48).

Dietler, M. 2007. "Culinary encounters: food, identity and colonialism," in Twiss 2007, 218-42.

Dobney, K. and A. Ervynck 2006. "To fish or not to fish? Evidence for the possible avoidance of fish consumption during the Iron Age around the North Sea," in C. Haselgrove and T. Moore (edd.), The Later Iron Age and beyond (Oxford) 403-18.

Eckardt, H. 2005. "The social distribution of Roman artefacts: the case of nail-cleaners and brooches in Britain," JRA 18, 139-60.

Fulford, M. 2004. "Economic structures," in M. Todd (ed.), A companion to Roman Britain (Oxford) 309-26.

Giacosa, I. G. 1992. A taste of ancient Rome (Chicago).

Goodburn, R. 1978. “Roman Britain in 1977: Croy Hill," Britannia 9, 413.

Goody, J. 1982. Cooking, cuisine and class. A study in comparative sociology (Cambridge).

Grant, A. 1984. "Animal husbandry in Wessex and the Thames Valley," in B. Cunliffe and D. Miles (edd.), Aspects of the Iron Age in central southern Britain (Oxford) 102-19.

Grant, A. 2004. "Animals and the economy and ideology of Roman Britain," in M. Todd (ed.), A companion to Roman Britain (Oxford) 371-92.

Grew, F. O. 1981. "Roman Britain in 1980: Moresby," Britannia 12, 325.

Griffith, W. B. 1993. "Excavations to the north-east of Wallsend Roman fort," The Arbeia Journal 2, 25-36.

Harris, S. A., J. P. Robinson and B. E. Juniper 2002. "Genetic clues to the origin of the apple," Trends in Genetics 18, 426-30.

Hill, J. D. 1995a. "The Pre-Roman Iron Age in Britain and Ireland (ca. 800 BC to AD 100): an overview," J. World Prehist. 9, 47-98.

Hill, J. D. 1995b. Ritual and rubbish in the Iron Age of Wessex (BAR 242, Oxford).

Hill, J. D. 2002. "Just about the potter's wheel? Using, making and depositing Middle and Later Iron Age pots in East Anglia," in A. Woodward and J. D. Hill (edd.), Prehistoric Britain: the ceramic basis (Oxford) 14360.

James, S. and M. Millett (edd.) 2001. Britons and Romans: advancing an archaeological agenda (CBA Res. Rep. 125).

Jones, B. and D. Mattingly 1993. An atlas of Roman Britain (Oxford).

Jones, M. 1991. "Food production and consumption - plants," in R. F. J. Jones (ed.), Britain in the Roman period: recent trends (Sheffield) 21-27.

Jones, M. 1996. "Plant exploitation," in T. C. Champion and J. R. Collis (edd.), The Iron Age of Britain and Ireland: recent trends (Sheffield) 29-40.

King, A. 1999. "Diet in the Roman world: a regional inter-site comparison of the animal bones," JRA 12, 168202.

Kislev, M. 1988. "Pinus pinea in agriculture, culture and cult," in H. J. Küster (ed.), Der Prähistorische Mensch und seine Umwelt. Festschrift für Udelgard Körber-Grohne (Stuttgart) 73-79.

Kreuz, A. 2004. "Landwirtschaft im Umbruch? Archaeobotanische Untersuchungen zu den Jahrhunderten um Christi Geburt in Hessen und Mainfranken," BerRGK 85, 97-313.

Lauwerier, R. 2002. "Animals as food for the soul," in K. Dobney and T. O'Connor (edd.), Bones and the man (Oxford) 63-71.

Livarda, A. and M. Van der Veen 2008. "Social access and dispersal of condiments in north-west Europe from the Roman to the medieval period," Vegetation History E Archaeobotany, Online First - DOI $10.1007 / \mathrm{s} 00334-008-0168-4$

Macaulay-Lewis, E. 2006. "The role of ollae perforatae in understanding horticulture, planting techniques, garden design and plant trade in the Roman world," in J.-P. Morel, J. T. Juan and J. C. Matalama (edd.), The archaeology of crops, fields and gardens (Bari) 207-19.

Máté, I. D. 1995. "Excavations of an enclosure system at Rough Castle, Falkirk," ProcSocAntScot 125, 48397.

Mattingly, D. 2006. An imperial possession. Britain in the Roman Empire (London).

Mattingly, D. 2004. "Being Roman: expressing identity in a provincial setting," JRA 17, 5-25.

Millett, M. 1992. The Romanization of Britain. An essay in archaeological interpretation (Cambridge). 


\section{Diversity and change in plant food consumption in Roman Britain 109}

Murphy, P. and R. G. Scaife 1991. "The environmental archaeology of gardens," in A. E. Brown (ed.), Garden archaeology (CBA Res. Rep. 78) 83-99.

Nicholson, K. 2006. A Late Iron Age and Romano-British farmstead at Cedars Park, Stowmarket, Suffolk (Hertford).

Pitts, M. 2005. "Pots and pits: drinking and deposition in Late Iron Age south-east Britain," OJA 24, 143-61.

Rees, S. E. 1979. Agricultural implements in Prehistoric and Roman Britain (BAR 69, Oxford).

Robinson, M. with N. Fulford and K. Tootell 2006. "The macroscopic plant remains," in M. Fulford, A. Clarke and H. Eckardt, Life and labour in Roman Silchester. Excavations in Insula IX since 1997 (Britannia Monog. 22) 206-18 and 374-79.

Stace, C. 1997. New flora of the British Isles (2nd edn., Cambridge).

Taylor, J. 2007. An atlas of Roman rural settlement in England (CBA Res. Rep. 151).

Ter Braak C. J. F. and P. Smilauer 2002. CANOCO Reference Manual and CanoDraw for Windows User's Guide (Wageningen).

Tomlinson, P. and A. Hall 1996. "A review of the archaeological evidence for food plants from the British Isles: an example of the use of the ArchaeoBotanical Computer Database (ABCD)," Internet Archaeology 1 (http://intarch.ac.uk/journal/issue1/tomlinson_index.html).

Twiss, K. C. (ed.) 2007. The archaeology of food and identity (Occ. Paper 34, Center for Archaeological Investigations, S. Illinois Univ., Carbondale).

Van der Veen, M. 2003. "When is food a luxury?" World Arch. 34, 405-27.

Van der Veen, M. 2007. "Food as an instrument of social change: feasting in Iron Age and early Roman southern England," in Twiss 2007, 112-29.

Van der Veen, M., A. Livarda and A. Hill 2007. "The archaeobotany of Roman Britain: current state and identification of research priorities," Britannia 38, 181-210.

Van der Veen, M., A. Livarda and A. Hill 2008. "New plant foods in Roman Britain: dispersal and social access," Environmental Archaeology 13(1), 11-36.

Vaughan, J. G. and C. A. Geissler 1997. The new Oxford book of plant foods (Oxford).

Wacher, J. 1975. The towns of Roman Britain (London).

Webster, J. 2001. "Creolizing the Roman provinces," AJA 105, 209-25.

Wheeler, A. 1981 in C. Partridge, Skeleton Green, A Late Iron Age and Romano-British site (Britannia Monog. 2) 242-43.

White, K. D. 1970. Roman farming (Ithaca, NY).

Williams, D. 1977. "A consideration of the sub-fossil remains of Vitis vinifera as evidence for viticulture in Roman Britain," Britannia 8, 327-34.

Willis, S. 2005. "Samian pottery, a resource for the study of Roman Britain and beyond: the results of the English Heritage funded Samian Project," Internet Archaeology 17 (http://intarch.ac.uk/journal /issue17/willis_index.html).

Zohary, D. and M. Hopf 1994. Domestication of plants in the Old World (2nd edn., Oxford). 